\title{
Kinetics of the $\mathrm{OH}+\mathrm{NO}_{2}$ reaction: rate coefficients $(217-333 \mathrm{~K}$, 16-1200 mbar) and fall-off parameters for $\mathrm{N}_{2}$ and $\mathrm{O}_{2}$ bath gases
}

\author{
Damien Amedro, Arne J. C. Bunkan, Matias Berasategui, and John N. Crowley \\ Division of Atmospheric Chemistry, Max-Planck-Institut für Chemie, 55128 Mainz, Germany
}

Correspondence: John N. Crowley (john.crowley@mpic.de)

Received: 29 March 2019 - Discussion started: 13 May 2019

Revised: 2 August 2019 - Accepted: 5 August 2019 - Published: 23 August 2019

\begin{abstract}
The radical terminating, termolecular reaction between $\mathrm{OH}$ and $\mathrm{NO}_{2}$ exerts great influence on the $\mathrm{NO}_{y} / \mathrm{NO}_{x}$ ratio and $\mathrm{O}_{3}$ formation in the atmosphere. Evaluation panels (IUPAC and NASA) recommend rate coefficients for this reaction that disagree by as much as a factor of 1.6 at low temperature and pressure. In this work, the title reaction was studied by pulsed laser photolysis and laser-induced fluorescence over the pressure range 16-1200 mbar and temperature range $217-333 \mathrm{~K}$ in $\mathrm{N}_{2}$ bath gas, with experiments at $295 \mathrm{~K}$ (67-333 mbar) for $\mathrm{O}_{2}$. In situ measurement of $\mathrm{NO}_{2}$ using two optical absorption set-ups enabled generation of highly precise, accurate rate coefficients in the fall-off pressure range, appropriate for atmospheric conditions.

We found, in agreement with previous work, that $\mathrm{O}_{2}$ bath gas has a lower collision efficiency than $\mathrm{N}_{2}$ with a relative collision efficiency to $\mathrm{N}_{2}$ of 0.74 . Using the Troe-type formulation for termolecular reactions we present a new set of parameters with $k_{0}\left(\mathrm{~N}_{2}\right)=2.6 \times 10^{-30} \mathrm{~cm}^{6}$ molecule ${ }^{-2} \mathrm{~s}^{-1}$, $k_{0}\left(\mathrm{O}_{2}\right)=2.0 \times 10^{-30} \mathrm{~cm}^{6}$ molecule ${ }^{-2} \mathrm{~s}^{-1}, m=3.6, k_{\infty}=$ $6.3 \times 10^{-11} \mathrm{~cm}^{3}$ molecule ${ }^{-1} \mathrm{~s}^{-1}$, and $F_{\mathrm{c}}=0.39$ and compare our results to previous studies in $\mathrm{N}_{2}$ and $\mathrm{O}_{2}$ bath gases.
\end{abstract}

\section{Introduction}

The capacity of the atmosphere to oxidize trace gases and thus cleanse itself of pollutant emissions depends on the availability of $\mathrm{OH}$ radicals, which initiate the degradation of many organic and inorganic trace gases (Lelieveld et al., 2004; Lelieveld et al., 2016). Two reactions, the photolysis of ozone in the presence of water vapour (Reactions R1 and R2) and the reaction of $\mathrm{HO}_{2}$ radicals with $\mathrm{NO}$ (Reaction $\mathrm{R} 3$ ), are responsible for a large fraction of atmospheric $\mathrm{OH}$ production.

$\mathrm{O}_{3}+h v \rightarrow \mathrm{O}\left({ }^{1} \mathrm{D}\right)+\mathrm{O}_{2}$

$\mathrm{O}\left({ }^{1} \mathrm{D}\right)+\mathrm{H}_{2} \mathrm{O} \rightarrow 2 \mathrm{OH}$

$\mathrm{HO}_{2}+\mathrm{NO} \rightarrow \mathrm{OH}+\mathrm{NO}_{2}$

$\mathrm{NO}_{2}$ is a key component in controlling atmospheric oxidation as it contributes via its photolysis (Reaction R4) to formation of tropospheric $\mathrm{O}_{3}$ but also, via the title reaction (Reaction R5), leads to removal of $\mathrm{OH}$.

$$
\begin{aligned}
\mathrm{NO}_{2}+h v\left(\mathrm{O}_{2}\right) & \rightarrow \mathrm{NO}+\mathrm{O}_{3} \\
\mathrm{OH}+\mathrm{NO}_{2}+M & \rightarrow \mathrm{HNO}_{3}+M \\
& \rightarrow \mathrm{HOONO}+M
\end{aligned}
$$

Atmospheric $\mathrm{HO}_{x}$ levels $\left(\mathrm{HO}_{x}=\mathrm{OH}+\mathrm{HO}_{2}\right)$ and $\mathrm{NO}_{x}$ levels $\left(\mathrm{NO}_{x}=\mathrm{NO}+\mathrm{NO}_{2}\right)$, from the boundary layer to the stratosphere, are strongly influenced by the radical terminating reaction (Reaction R5) between the hydroxyl radical $(\mathrm{OH})$ and nitrogen dioxide $\left(\mathrm{NO}_{2}\right)$. Reaction $\mathrm{R} 5$ is complex, with its rate coefficient displaying both a pressure and temperature dependence and two different reaction pathways, leading to either nitric acid $\left(\mathrm{HNO}_{3}\right)$ or pernitrous acid (HOONO). $\mathrm{HNO}_{3}$ is the dominant product under atmospheric conditions and its long lifetime with respect to reformation of $\mathrm{OH}$ and $\mathrm{NO}_{2}$ (via reaction with $\mathrm{OH}$ or photolysis) and rapid deposition to surfaces in the boundary layer mean that Reaction R5 is effectively a sink of both $\mathrm{OH}$ and $\mathrm{NO}_{2}$. The yield of HOONO increases as a function of pressure, with a value of $\sim 14 \%$ at atmospheric pressure $(T=298 \mathrm{~K})$ (Golden et al., 2003; Hippler et al., 2002; Mollner et al., 2010). The fate of HOONO is thought to be dominated by 
thermal decomposition at temperatures typical of the midlatitude boundary layer, with the reaction with $\mathrm{OH}$ and photolysis potentially contributing at higher altitudes and lower temperatures where its thermal lifetime is longer. The impact of the title reaction as a $\mathrm{HO}_{x}$ and $\mathrm{NO}_{x}$ sink thus depends on the relative efficiency of formation of $\mathrm{HNO}_{3}$ and $\mathrm{HOONO}$ and the fate of HOONO, investigation of which is beyond the scope of this study.

Whilst the importance of the reaction between $\mathrm{OH}$ and $\mathrm{NO}_{2}$ has been recognized for a long time, and is reflected in the numerous studies of the kinetics of this process (see e.g. evaluations of the kinetic data; Atkinson et al., 2006; Burkholder et al., 2015; IUPAC, 2019), a recent modelling study has indicated that uncertainties in the rate coefficient have a great impact on the simulated chemical composition of the atmosphere (Newsome and Evans, 2017). The recommended parameterizations of the independent, expert evaluation panels, IUPAC (IUPAC, 2019) and NASA (Burkholder et al., 2015), for the rate coefficient $\left(k_{5}\right)$ of the title reaction deviate to an unacceptable extent given the importance of this reaction. Figure 1 illustrates how the ratio of the rate coefficients recommended by IUPAC and NASA $\left(k_{5}^{\mathrm{IUPAC}} / k_{5}^{\mathrm{NASA}}\right)$ varies with altitude, and thus pressure and temperature. Up to the tropopause $(\sim 10 \mathrm{~km}$ at mid-latitudes), the difference between $k_{5}^{\text {IUPAC }}$ and $k_{5}^{\text {NASA }}$ is about $10 \%$ but this increases to $60 \%$ at an altitude of $30 \mathrm{~km}$ where the pressure and temperature of the stratosphere are low. The lack of consensus between the IUPAC and NASA panels (drawing from the same laboratory-derived datasets) reflects, in part, the complexity of the reaction, the study of which requires coverage of parameter space (pressure and temperature) that demands the use of different experimental methods. Reaction R5 is an association reaction (termolecular process) and the pressure and temperature dependence stems from stabilization of the initially formed association complex, which can dissociate back to reactants at low pressure or proceed to formation of products at high pressure. These types of reactions are generally parameterized using so-called fall-off curves (Troe, 1983, 2012), which require measurement of the rate coefficients at the low- and high-pressure limits, $k_{0}$ and $k_{\infty}$ respectively. The form of the transition between the lowpressure limit, at which the rate coefficient is roughly proportional to pressure, and the high-pressure limit, at which the association complex is fully stabilized, is characterized by a broadening parameter, $F_{\mathrm{c}}$. The low- and high-pressure limits have to be characterized experimentally, whereas the broadening factor can be estimated (Cobos and Troe, 2003). The IUPAC and NASA evaluation panels take different approaches to the broadening factor, with IUPAC quoting values that vary between $\sim 0.3$ and 0.6 and NASA taking the more pragmatic approach of fixing $F_{\mathrm{c}}$ at 0.6 , which may be justified in many circumstances given the uncertainties associated with $k_{\infty}$ (see below). We show later that, for the $\mathrm{OH}+\mathrm{NO}_{2}$ reaction, the data are better parameterized using a value of $F_{\mathrm{c}}$ close to the theoretical value of 0.39 .

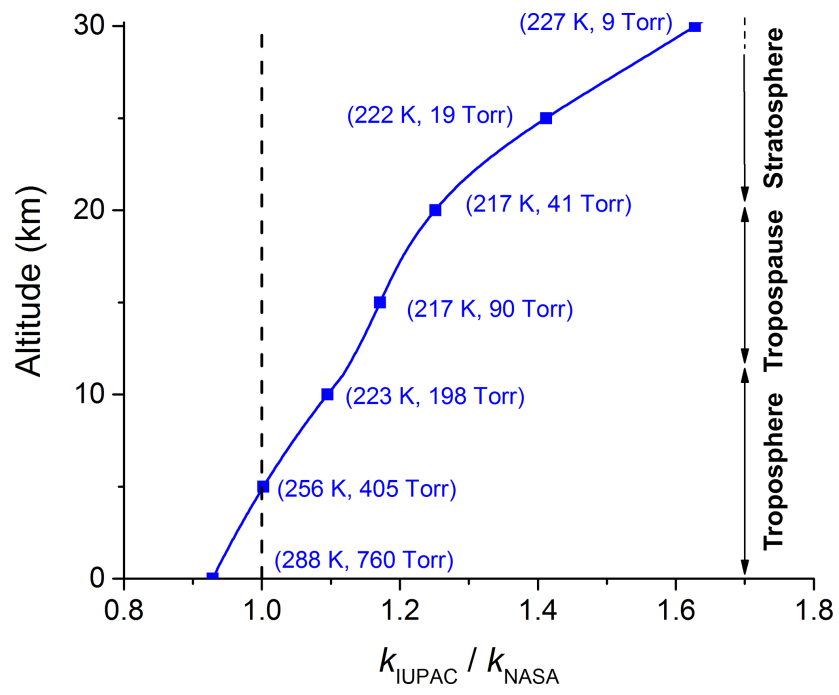

Figure 1. Ratio of the parameterized IUPAC and NASA rate coefficients $\left(k_{5}\right)$ at various altitudes (temperatures and pressures).

The difficulty in parameterizing the rate coefficient for the reaction between $\mathrm{OH}$ and $\mathrm{NO}_{2}$ lies in the fact that, across the range of temperatures and pressures that prevail in our atmosphere, the reaction is in the fall-off regime, yet the high-pressure limit is not accessible with standard methods. We show later that experiments conducted at pressures as high as 500 bar $\mathrm{He}$ are still below the high-pressure limit and that experiments at pressures as low as 5 Torr $\mathrm{N}_{2}$ $(1$ Torr $=1.33 \mathrm{mbar}=133 \mathrm{~Pa})$ are already impacted by falloff. Only three previous studies (Anastasi and Smith, 1976; D'Ottone et al., 2001; Mollner et al., 2010) have determined the rate coefficient at pressures close to 1 bar. Further complexity is added by the fact that the efficiency of collisional deactivation of the association complex is, in contrast to the overwhelming majority of termolecular reactions of atmospheric relevance, different for $\mathrm{N}_{2}$ and $\mathrm{O}_{2}$, the major atmospheric "third-body" bath gases ( $M$ in Reaction R5).

The overall aim of this research was to reduce the uncertainty associated with the rate coefficient in $\mathrm{N}_{2}$ and $\mathrm{O}_{2}$ by generating an additional highly accurate dataset over a wide range of pressures and temperatures relevant for the atmosphere. To do this we have used the pulsed laser photolysis and laser-induced-fluorescence technique coupled with in situ measurement of $\mathrm{NO}_{2}$ concentrations. We note that the rate coefficients we obtain represent the total loss rate coefficient $\left(k_{5}\right)$ for $\mathrm{OH}$ loss (i.e. the sum of $k_{5 a}$ and $k_{5 b}$ ). 


\section{Experimental details}

\subsection{PLP-LIF technique}

Rate coefficients for the title reaction were measured using pulsed laser photolysis (PLP) for generation of $\mathrm{OH}$ and laserinduced fluorescence (LIF) to detect it in real time. The details of the experimental set-up have been published previously (Wollenhaupt et al., 2000) and only a brief description is given here. The experiments were carried out in a quartz reactor of volume $\sim 500 \mathrm{~cm}^{3}$, which was thermostatted to the desired temperature by circulating a $60: 40$ mixture of ethylene glycol / water or ethanol through an outer jacket. The pressure in the reactor was monitored with 100 and 1000 Torr capacitance manometers (MKS). For all experiments, the axial flow velocity in the reactor was kept roughly constant at $\sim 10 \mathrm{~cm} \mathrm{~s}^{-1}$ by adjusting the flow rate from 270 and $9900 \mathrm{~cm}^{3}$ (STP) $\mathrm{min}^{-1}$ (sccm). As the $\sim 8 \mathrm{~mm}$ wide laser beam was normal to the direction of flow, this ensured that a fresh gas sample was available for photolysis at each laser pulse (laser frequency $=10 \mathrm{~Hz}$ ). We additionally carried out some experiments at a lower repetition rate $(5 \mathrm{~Hz})$ to help rule out any influence of product build-up on the measured rate coefficient.

Pulses of $248 \mathrm{~nm}$ laser light ( $\sim 20 \mathrm{~ns}$ ) for $\mathrm{OH}$ generation from $\mathrm{HNO}_{3}$ and $\mathrm{H}_{2} \mathrm{O}_{2}$ precursors were provided by an excimer laser (Compex 205 F, Coherent) operated using KrF.

$$
\begin{aligned}
& \mathrm{HNO}_{3}+h v(248 \mathrm{~nm}) \rightarrow \mathrm{OH}+\mathrm{NO}_{2} \\
& \mathrm{H}_{2} \mathrm{O}_{2}+h v(248 \mathrm{~nm}) \rightarrow 2 \mathrm{OH}
\end{aligned}
$$

Laser fluences were measured using a calibrated joule meter located behind the exit window of the reactor.

The concentrations of $\mathrm{H}_{2} \mathrm{O}_{2}$ and $\mathrm{HNO}_{3}$ were typically in the range $5-10 \times 10^{13}$ and $5-10 \times 10^{14}$ molecule $\mathrm{cm}^{-3}$ respectively, which, when combined with laser fluences of 5$40 \mathrm{~mJ} \mathrm{~cm}^{-2}$ per pulse, resulted in initial $\mathrm{OH}$ concentrations of $\sim 1-12 \times 10^{11}$ molecule $\mathrm{cm}^{-3}$. We show later that variation in the initial radical concentration in this range had no effect on the results obtained, as expected for this chemical system.

$\mathrm{OH}$ fluorescence was detected using a photomultiplier tube screened by a $309 \mathrm{~nm}$ interference filter and a BG 26 glass cut-off filter following excitation of the $\mathrm{OH} A^{2} \Sigma\left(v^{\prime}=\right.$ 1) $\leftarrow X^{2} \Pi\left(v^{\prime \prime}=0\right)$ transition (Q11(1)) at $281.997 \mathrm{~nm}$ using a YAG-pumped dye laser (Quantel Brilliant B and Lambda Physik Scanmate). The time-dependent fluorescence signal was accumulated using a boxcar integrator triggered at different delay times between $\mathrm{OH}$ formation and excitation.

A second fluorescence detection axis was set up to enable detection of $\mathrm{NO}_{2}$ in the same volume as $\mathrm{OH} . \mathrm{NO}_{2}$ was excited at $\sim 564 \mathrm{~nm}$ (Rhodamine $6 \mathrm{G}$ dye pumped by a frequency-doubled YAG at $532 \mathrm{~nm}$ ) and the resulting fluorescence emission was detected using a multi-alkali photomultiplier tube screened by a $605 \mathrm{~nm}$ long-pass filter. The boxcar gate was timed to discriminate laser-scattered light from the
$\mathrm{NO}_{2}$ fluorescence. The $\mathrm{NO}_{2} \mathrm{LIF}$ signal was normalized to laser power using a photodiode sampling a fraction of the excitation pulse.

\subsection{Online absorption measurement of $\mathrm{NO}_{2}$ concentration}

The experiments to determine the rate coefficient of the title reaction were performed under pseudo-first-order conditions (i.e. $\left.\left[\mathrm{NO}_{2}\right]_{0} \gg[\mathrm{OH}]_{0}\right)$. As a result, the overall uncertainty in $k_{5}$ was determined largely by the accuracy with which the $\mathrm{NO}_{2}$ concentration was measured. Depending on the experimental conditions ( $T, p$, and bath gas), the $\mathrm{NO}_{2}$ concentration was varied from 1 to $45 \times 10^{14}$ molecule $\mathrm{cm}^{-3}$.

The $\mathrm{NO}_{2}$ concentration was continuously measured using two optical absorption cells at room temperature. In the first, upstream of the reactor, absorption of light $(405-440 \mathrm{~nm})$ from the collimated output from a halogen lamp transversed a $110 \mathrm{~cm}$ long absorption cell before being dispersed with a $0.5 \mathrm{~m}$ monochromator (B \& M Spektronik BM50, 600 grooves per millimetre, blaze at $500 \mathrm{~nm}$ ) and detected by a diode-array detector (Oriel InstaSpec 2 ). The effective spectral resolution $(\delta \lambda=0.19 \mathrm{~nm})$ of the monochromatordetector set-up was obtained by measuring the width and line shape (Gaussian) of the $404.66 \mathrm{~nm} \mathrm{Hg}$ line from a lowpressure $\mathrm{Hg}$ lamp. $\mathrm{NO}_{2}$ concentrations were determined by fitting optical densities (ODs) from 405 to $440 \mathrm{~nm}$ to a reference spectrum (Vandaele et al., 2002) (see Sect. 3.1), which was degraded to the resolution of our spectrometer. The second optical absorption cell (dual beam for simultaneous measurement of transmitted and reference light intensity, $43.8 \mathrm{~cm}$ long) was located downstream of the reactor. Here the extinction of $365 \mathrm{~nm}$ light from a low-pressure Hg lamp screened using a $365 \pm 5 \mathrm{~nm}$ interference filter was used to continuously monitor $\mathrm{NO}_{2}$ at this wavelength.

The effective $\mathrm{NO}_{2}$ cross section at $365 \mathrm{~nm}\left(\sigma_{365}\right.$; see Sect. 3.2) was determined by simultaneously monitoring the $\mathrm{NO}_{2}$ concentration in the first absorption cell and measuring $365 \mathrm{~nm}$ extinction in the second absorption cell. $\sigma_{365}$ was calculated using the Beer-Lambert law:

$\mathrm{OD}_{365}=\ln \left(\frac{I_{0}}{I}\right)=\sigma_{365}\left[\mathrm{NO}_{2}\right] l$,

where $l$ is the optical path length $(43.8 \mathrm{~cm})$ and $I_{0}$ and $I$ are the transmitted light intensities at $365 \mathrm{~nm}$ in the absence and in the presence of $\mathrm{NO}_{2}$ respectively. The limit of detection of $\mathrm{NO}_{2}$ (defined as $2 \sigma$ of the signal in the absence of absorbent) was determined to be $\sim 1 \times 10^{13}$ molecule $\mathrm{cm}^{-3}$ for both the single wavelength $(365 \mathrm{~nm})$ and broadband $(405-440 \mathrm{~nm})$ absorption measurements. Drifts in zero measurements result in the smallest measurable OD in the $365 \mathrm{~nm}$ cell of $\sim 1 \times$ $10^{-4}$, which is equivalent to $4.0 \times 10^{12}$ molecule $\mathrm{cm}^{-3} \mathrm{NO}_{2}$.

A third optical absorption cell $(\lambda=184.95 \mathrm{~nm}, l=$ $40.0 \mathrm{~cm}$ ) was also used to measure optical extinction by $\mathrm{NO}_{2}$ in experiments in which we explored the effect of pressure 
on $\sigma_{\mathrm{NO}_{2}}$. Light at $184.95 \mathrm{~nm}$ was provided by a low-pressure Hg lamp screened by a $185 \pm 5 \mathrm{~nm}$ interference filter and was detected using a dual-beam set-up similar to that operated at $365 \mathrm{~nm}$.

\subsection{Chemicals}

$\mathrm{N}_{2}$ and $\mathrm{O}_{2}$ (Westfalen $99.999 \%$ ) were used without further purification. $\mathrm{H}_{2} \mathrm{O}_{2}$ (AppliChem, $50 \mathrm{wt} \%$ ) was concentrated to $>90 \%$ (wt) by vacuum distillation. Anhydrous nitric acid was prepared by mixing $\mathrm{KNO}_{3}$ (Sigma Aldrich, 99\%) and $\mathrm{H}_{2} \mathrm{SO}_{4}$ (Roth, $98 \%$ ), and condensing $\mathrm{HNO}_{3}$ vapour into a liquid nitrogen trap. $\mathrm{NO}_{2}$ was generated via the reaction of $\mathrm{NO}$ with a large excess of $\mathrm{O}_{2}$. The $\mathrm{NO}_{2}$ thus was trapped in liquid $\mathrm{N}_{2}$ and the excess $\mathrm{O}_{2}$ was pumped out. The resulting $\mathrm{NO}_{2}$ was stored as a mixture of $\sim 0.5 \% \mathrm{NO}_{2}$ in $\mathrm{N}_{2}$ or $\sim 5.5 \% \mathrm{NO}_{2}$ in He. NO (3.5 Air Liquide) was purified of higher $\mathrm{NO}_{x}$ compounds by fractional vacuum distillation.

\section{Results and discussion}

\section{1 $\mathrm{NO}_{2}$ concentration measurement}

As $\mathrm{NO}_{2}$ concentrations were monitored in situ by optical absorption at $365 \mathrm{~nm}$, the cross section determination was centrally important for derivation of the rate coefficient and considerable effort was dedicated to its accurate determination, with special attention paid to its pressure dependence.

\subsubsection{Pressure dependence of the $\mathrm{NO}_{2}$ absorption cross section at $365 \mathrm{~nm}$}

$\mathrm{NO}_{2}$ has a complex and highly structured absorption spectrum in the UV-visible region with band shapes and line intensities depending on both temperature and pressure (Atkinson et al., 2004; IUPAC, 2019). The atomic Hg lines, used to determine $\left[\mathrm{NO}_{2}\right]$ in this work, are very narrow and therefore pressure broadening of $\mathrm{NO}_{2}$ lines around $365 \mathrm{~nm}$ could affect the retrieved concentration. We performed two experiments (at room temperature) that indicate that, from 20 to 800 Torr of $\mathrm{N}_{2}$, any pressure dependence in the $\mathrm{NO}_{2}$ absorption cross section at $365 \mathrm{~nm}$ can safely be neglected.

In the first experiment, we simultaneously monitored optical extinction due to a flowing sample of $\mathrm{NO}_{2}$ in $\mathrm{N}_{2}$ at 184.95 and $365 \mathrm{~nm}$. Whereas the $\mathrm{NO}_{2}$ spectrum around $365 \mathrm{~nm}$ is highly structured (corresponding to excitation from the ground electronic state to the $(1)^{2} B_{2}$ state), in the vacuum UV (180-220 nm) the spectrum obtained following excitation to the $(2)^{2} B_{2}$ electronic state is largely continuous in nature ( $\mathrm{Au}$ and Brion, 1997). It is highly unlikely that any pressure broadening effects for these two transitions/spectral regions will be identical. Figure 2a displays the result of a series of experiments in which the optical density (OD) observed for $\mathrm{NO}_{2}$ concentrations between $2 \times 10^{14}$ and $4 \times 10^{15}$ molecule $\mathrm{cm}^{-3}$ at three different pressures (20,
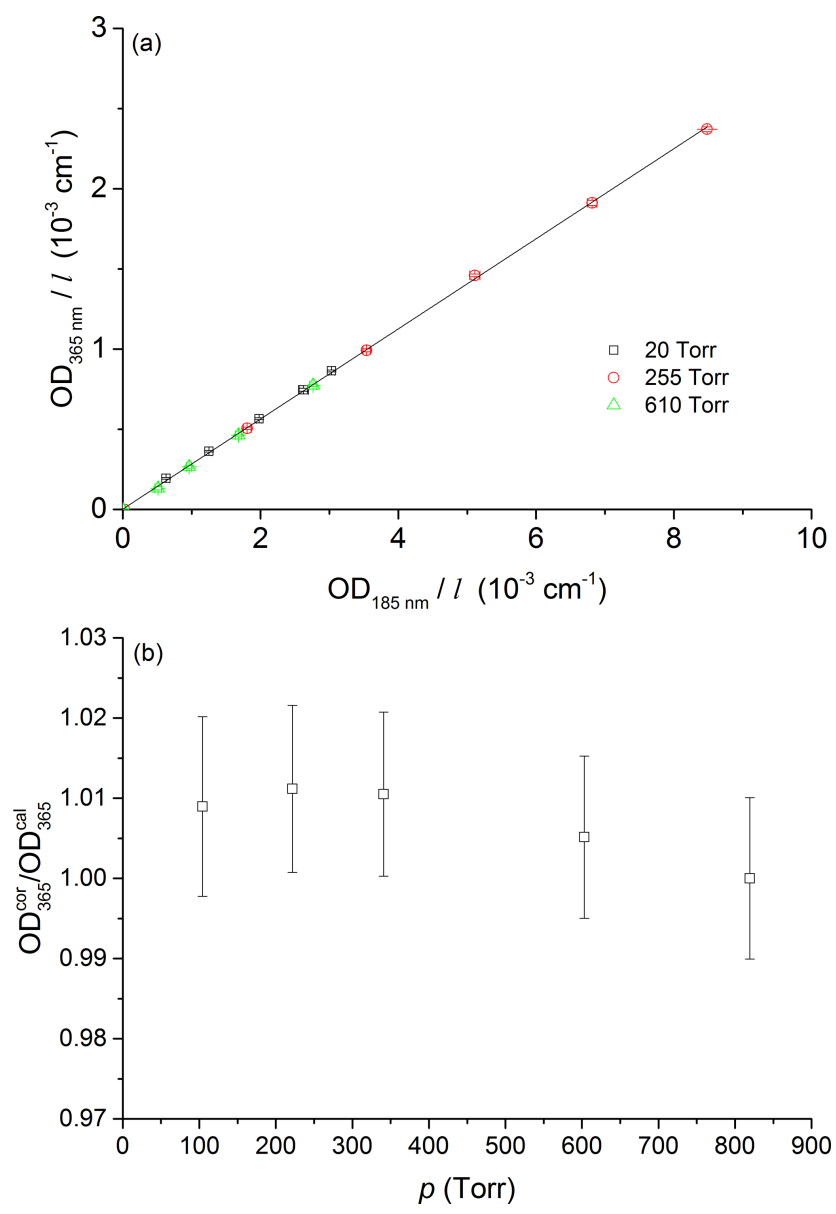

Figure 2. Pressure dependence of the relative $\mathrm{NO}_{2}$ absorption cross section, $\sigma_{365 \mathrm{~nm}} / \sigma_{185 \mathrm{~nm}}$, at 185 and $365 \mathrm{~nm}$. The solid line is a linear regression for all three datasets giving a slope of $0.281 \pm 0.002$ (uncertainty is $2 \sigma$, statistical only). Panel (b) shows the slopes obtained at 20, 255, and 610 Torr plotted versus pressure. The measurements were performed at room temperature.

255 , and 610 Torr $\mathrm{N}_{2}$ ) was recorded simultaneously in the two optical absorption cells. The ODs were corrected for a slight pressure (and thus concentration) difference between the two optical absorption cells and normalized to an optical path length of $1 \mathrm{~cm}$ to obtain the parameters $\mathrm{OD}_{365}^{\mathrm{cor}}$ and $\mathrm{OD}_{185}^{\text {cor }}$. The linear regression of a plot of $\mathrm{OD}_{365}^{\text {cor }}$ versus $\mathrm{OD}_{185}^{\text {cor }}$ yields a value of $\mathrm{OD}_{365}^{\text {cor }} / \mathrm{OD}_{185}^{\text {cor }}=0.282 \pm 0.004$ (uncertainty is $2 \sigma$ ) and, within $1 \%$, is independent of pressure.

In a second set of experiments, the optical density at $365 \mathrm{~nm}\left(\mathrm{OD}_{365}\right)$ from $2.1 \times 10^{16}$ molecule $\mathrm{cm}^{-3} \mathrm{NO}_{2}$ in 820 Torr of $\mathrm{N}_{2}$ was initially recorded. The optical absorption cell was then evacuated stepwise to 100 Torr and $\mathrm{OD}_{365}$ recorded at each pressure. The $\mathrm{NO}_{2}$ samples contained $\mathrm{N}_{2} \mathrm{O}_{4}$ in equilibrium with $\mathrm{NO}_{2}$ (Reactions $\mathrm{R} 8$ and $\mathrm{R} 9$ ).

$$
\begin{aligned}
& \mathrm{NO}_{2}+\mathrm{NO}_{2}+M \rightarrow \mathrm{N}_{2} \mathrm{O}_{4}+M \\
& \mathrm{~N}_{2} \mathrm{O}_{4}+M \rightarrow 2 \mathrm{NO}_{2}+M
\end{aligned}
$$


Using the equilibrium coefficient of $2.6 \times$ $10^{-19} \mathrm{~cm}^{3}$ molecule ${ }^{-1}$ (average from IUPAC and NASA panels at $298 \mathrm{~K}$ ) we calculated a $\mathrm{N}_{2} \mathrm{O}_{4} / \mathrm{NO}_{2}$ ratio that changed from $5.9 \times 10^{-3}$ at 820 Torr $\left(\left[\mathrm{NO}_{2}\right]=2.1 \times 10^{16}\right.$ molecule $\left.\mathrm{cm}^{-3}\right)$ to $7.0 \times 10^{-4}$ at 100 Torr $\left(\mathrm{NO}_{2}=2.56 \times 10^{15}\right.$ molecule $\left.\mathrm{cm}^{-3}\right) . \mathrm{OD}_{365}$ was thus corrected $(<0.3 \%)$ for the absorption of $\mathrm{N}_{2} \mathrm{O}_{4}$ at $365 \mathrm{~nm} \quad\left(\sigma_{365 \mathrm{~nm}} \quad\left(\mathrm{~N}_{2} \mathrm{O}_{4}\right)=3 \times 10^{-19} \mathrm{~cm}^{2}\right.$ molecule ${ }^{-1}$, Burkholder et al., 2015) and for the small change in $\left[\mathrm{NO}_{2}\right]$ resulting from the shift in equilibrium as the pressure and thus $\mathrm{NO}_{2}$ concentration were reduced. We also corrected for $\mathrm{NO}_{2}$ depletion due to photolysis (to $\mathrm{NO}$ and $\mathrm{O}\left({ }^{3} \mathrm{P}\right), \Phi=1$ ) caused by absorption of the $365 \mathrm{~nm}$ light. The photolytic loss rate constant of $\mathrm{NO}_{2}$ was determined in a separate experiment to be $8 \times 10^{-6} \mathrm{~s}^{-1}$, which requires a correction in $\left[\mathrm{NO}_{2}\right]$ of $<0.2 \%$ on the timescale of the experiment. Altogether, the corrections outlined above accounted for less than $2 \%$ of the measured optical density.

In the absence of a pressure dependence of the effective absorption cross section of $\mathrm{NO}_{2}$ at $365 \mathrm{~nm}$, the ratio of measured optical density $\left(\mathrm{OD}_{365}^{\mathrm{cor}}\right)$ to that calculated directly $\left(\mathrm{OD}_{365}^{\mathrm{calc}}\right)$ from the initial concentration at 820 Torr and the subsequent changes in pressure should not deviate from unity. Figure $2 \mathrm{~b}$ plots $\mathrm{OD}_{365}^{\mathrm{cor}} / \mathrm{OD}_{365}^{\mathrm{cal}}$ (normalized to the measurement at 820 Torr) against pressure and indicates that within an experimental uncertainty of $2 \%$, no pressure dependence in the $\mathrm{NO}_{2}$ absorption cross section at $365 \mathrm{~nm}$ is observed.

The two sets of experiments described above show that there is no significant $(<2 \%)$ pressure dependence in the effective cross section of $\mathrm{NO}_{2}$ at $365 \mathrm{~nm}$.

\subsubsection{Comparison of $\mathrm{NO}_{2}$ literature spectra}

The $\mathrm{NO}_{2}$ visible spectra have already been reviewed (Orphal, 2003) and we extend this to include the more recent highresolution work by Nizkorodov et al. (2004) as it was used as a reference in a recent kinetic study of $\mathrm{OH}+\mathrm{NO}_{2}$ (Mollner et al., 2010). At ultra-high resolution, rovibrational lines in the $\mathrm{NO}_{2}$ spectrum broaden at higher pressures and the two more recent studies by Vandaele et al. (2002) and Nizkorodov et al. (2004) reported pressure broadening factors $\gamma$ ( $\gamma$ being the half width at half maximum of a Lorentzian) in air of 0.081 and $0.116 \mathrm{~cm}^{-1} \mathrm{~atm}^{-1}$ respectively, corresponding to $\sim 0.0013$ and $\sim 0.0019 \mathrm{~nm}$ at $1 \mathrm{~atm}$ and $405 \mathrm{~nm}$ respectively. Using the broadening factors above, one can generate spectra at any pressure by convoluting a pressure-dependent Lorentzian line width to a $\mathrm{NO}_{2}$ spectrum obtained at low pressure and then degrading it (using a Gaussian slit function) to the resolution of the spectrometer. When applying these convolutions to the Vandaele et al. (2002) dataset, we found no difference in cross sections when using their spectra obtained at higher pressure or when using a calculated, pressure-broadened spectrum obtained at low pressure.
We also fitted our experimental measurement of $\mathrm{NO}_{2}$ optical density (405 to $440 \mathrm{~nm}$ ) using the lower-resolution spectra reported by Merienne et al. (1995) and Yoshino et al. (1997). Use of these reference spectra resulted in excellent agreement with those from Vandaele et al. (2002). This reflects the fact that although line widths increase at increasing pressure, once degraded to our spectral resolution, there is no discernible change in the cross sections in the $410-440 \mathrm{~nm}$ range. The same conclusion can be drawn when working with the spectra of Nizkorodov et al. (2004) that were obtained at pressures of $<75$ Torr. In contrast, using the $\mathrm{NO}_{2}$ spectra of Nizkorodov et al. (2004), which were recorded at pressures $\geq 75$ Torr, resulted in an overestimation of the $\mathrm{NO}_{2}$ concentration by up to $20 \%$ (at 596 Torr) when compared to those listed above. For these reasons, we use the spectrum reported by Vandaele et al. (2002) measured at 80 Torr as a reference spectrum throughout this work. We emphasize that use of any other spectrum (including the Nizkorodov spectrum obtained at low pressure and subsequently broadened (using their parameters) to any other pressure would have no significant impact $(<\sim 3 \%)$ on the cross section we derived at $365 \mathrm{~nm}$.

\subsubsection{Effective absorption cross section at $365 \mathrm{~nm}$}

The effective cross section of $\mathrm{NO}_{2}$ at $365 \mathrm{~nm}$ was determined by measuring its concentration in the $110 \mathrm{~cm}$ optical cell using the spectrum of Vandaele et al. (2002) between 400 and $450 \mathrm{~nm}$ and simultaneously monitoring the optical density at $365 \mathrm{~nm}$. An example of data used to retrieve the $\mathrm{NO}_{2}$ concentration using the measured optical density (405 to $440 \mathrm{~nm}$ ) and the spectrum of Vandaele et al. (2002) is given in Fig. 3a.

Figure $3 \mathrm{~b}$ shows the Beer-Lambert plot used to determine the $365 \mathrm{~nm} \mathrm{NO} 2$ absorption cross section at room temperature and 190 Torr of $\mathrm{N}_{2}$. The effective cross section derived from the slope is $(5.89 \pm 0.35) \times 10^{-19} \mathrm{~cm}^{2}$ molecule ${ }^{-1}$. The total uncertainty $(6 \%$ at $2 \sigma)$ takes into account the spread in absorption cross sections $(400-450 \mathrm{~nm})$ reported in the literature (Merienne et al., 1995; Yoshino et al., 1997; Vandaele et al., 1998, 2002). Our effective cross section at $365 \mathrm{~nm}$ is in excellent agreement with previous values of $(5.75 \pm 0.17) \times 10^{-19} \mathrm{~cm}^{2}$ molecule ${ }^{-1}$ reported by Wine et al. (1979) and D'Ottone et al. (2001), also obtained using low-pressure $\mathrm{Hg}$ lamps as emission-line sources.

\subsubsection{Detection of $\mathrm{NO}_{2}$ by $\mathrm{LIF}$ and $\mathrm{NO}_{2}$ dimerization at low temperatures}

At low temperatures and/or high $\mathrm{NO}_{2}$ concentration, $\mathrm{NO}_{2}$ partially dimerizes to $\mathrm{N}_{2} \mathrm{O}_{4}$ (Reactions $\mathrm{R} 8$ and R9), which will lead to differences in the $\mathrm{NO}_{2}$ concentrations derived from the optical absorption measurements at room temperatures with respect to those in the reactor where the $\mathrm{OH}+\mathrm{NO}_{2}$ reaction is investigated. Indeed, at very low temperature, a plot of first-order $\mathrm{OH}$ loss constant versus $\mathrm{NO}_{2}$ 

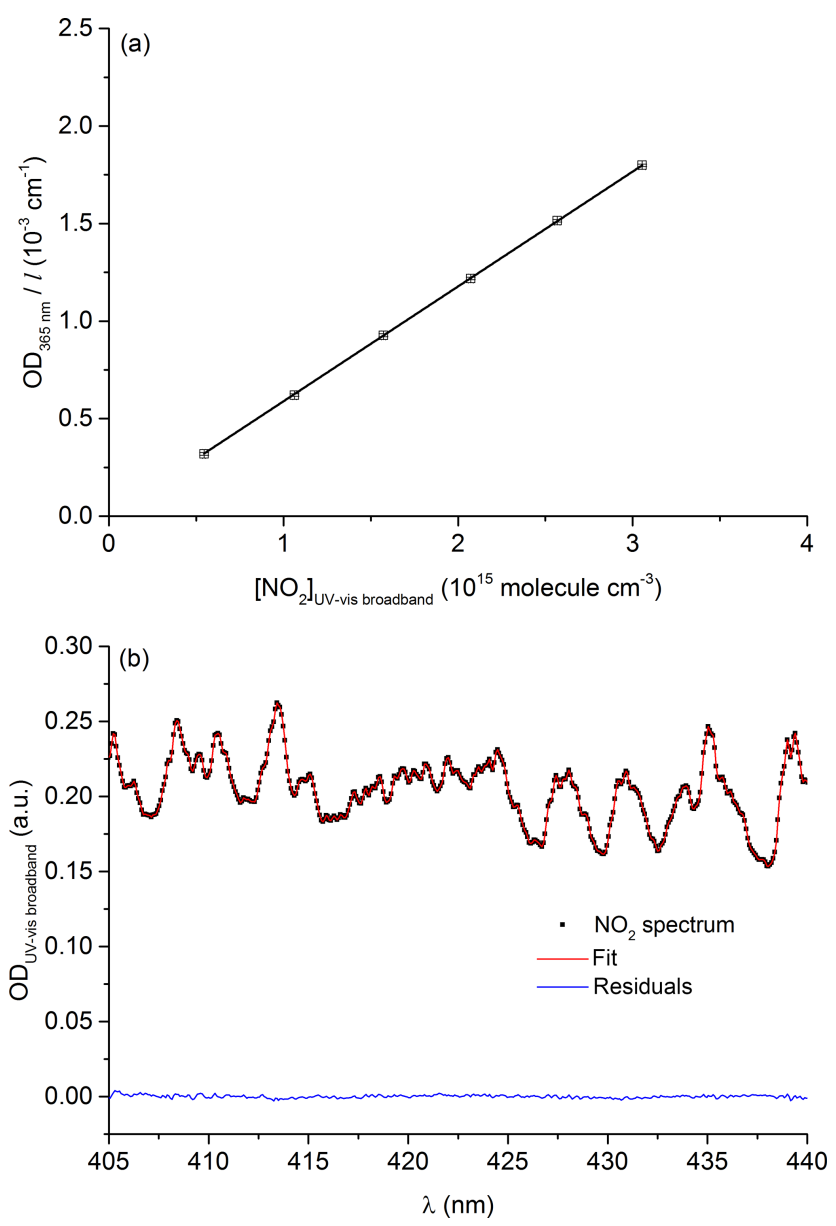

Figure 3. (a) Beer-Lambert plot of $\mathrm{OD}_{365 \mathrm{~nm}} / l$ as a function of $\left[\mathrm{NO}_{2}\right]$ (determined using the long-path UV-vis broadband cell) used to determine the $\mathrm{NO}_{2}$ effective cross section at $365 \mathrm{~nm}$, $\sigma_{365 \mathrm{~nm}}=(5.89 \pm 0.24) 10^{-19} \mathrm{~cm}^{2}$ molecule ${ }^{-1}$. (b) Example of a $\mathrm{NO}_{2}$ spectrum (squares) recorded using the long-path UV-vis broadband cell. The red line shows the fit to the reference spectrum. The blue line is the residual. The experiments were performed at $297 \mathrm{~K}$ and 185 Torr.

concentration as measured by optical absorption flattens at high $\left[\mathrm{NO}_{2}\right]$ due to the overestimation of the $\mathrm{NO}_{2}$ concentration in the reactor. This is illustrated in Fig. S1 of the Supplement.

The $\mathrm{NO}_{2}$ concentration in the cold reactor may be calculated using the following expression (Brown et al., 1999).

$\left[\mathrm{NO}_{2}\right]=\frac{\left(\sqrt{8\left[\mathrm{NO}_{2}\right]_{0} K_{8}+1}\right)-1}{4 K_{8}}$,

where $\left[\mathrm{NO}_{2}\right]_{0}$ is the measured concentration in the absorption cells at room temperature and $K_{8}$ is the equilibrium constant for Reactions R8 and R9.

At $217 \mathrm{~K}, K_{8}$ is associated with an uncertainty of > $50 \%$ (Atkinson et al., 2004; Burkholder et al., 2015; IUPAC, 2019) with the value given by IUPAC $\sim 65 \%$ smaller than that given by NASA. At $217 \mathrm{~K}$ and $\left[\mathrm{NO}_{2}\right]=5 \times$
$10^{14}$ molecule $\mathrm{cm}^{-3}$, the different recommendations would lead to a $\sim 13 \%$ difference in $\mathrm{NO}_{2}$. Even if $K_{8}$ were accurately known, thermal gradients along the length of the reactor and between the walls and the centre of the reactor (where we monitor $\mathrm{OH}$ kinetics) could potentially lead to concentration gradients of $\mathrm{NO}_{2}$ and thus to a difference between the concentrations derived from the optical absorption measurements. For these reasons, we checked the validity and the magnitude of the correction that needed to be applied to $\left[\mathrm{NO}_{2}\right]$ at low temperatures by performing series of measurements where $\left[\mathrm{NO}_{2}\right]$ was measured simultaneously by in situ LIF and UV absorption ([NO $\left.\left.\mathrm{NO}_{2}\right]_{\mathrm{UV}}\right)$ at different temperatures from 218 to $320 \mathrm{~K}$ and constant density $\left(1.65 \times 10^{18}\right.$ molecule $\mathrm{cm}^{-3}$; corresponding to 50 Torr at $292 \mathrm{~K})$.

Figure 4 displays the $\mathrm{NO}_{2}$ LIF signal at six different temperatures $(218,234,257,274,292$, and $320 \mathrm{~K})$ as a function of the $\mathrm{NO}_{2}$ concentration measured by ex situ optical absorption at room temperature. For the three highest temperatures, where $\mathrm{N}_{2} \mathrm{O}_{4}$ formation is negligible at the concentrations used, there is a strictly linear dependence of the LIF signal on $\left[\mathrm{NO}_{2}\right]$ and no measurable change in the LIF sensitivity with temperature. The latter indicates that any dependence of the LIF efficiency on temperature is very weak. As far as we are aware, none of the previous studies of $\mathrm{NO}_{2}$ fluorescence quenching have reported a temperature dependence of the fluorescence quenching rate constant for $\mathrm{N}_{2}$ (Keil et al., 1980). Only Schurath et al. (1981) report a weak negative $T$ dependence $\left(T^{-0.42}\right)$ on the fluorescence quenching rate constant for $\mathrm{NO}_{2} *$ (formed in the $\mathrm{NO}+\mathrm{O}_{3}$ reaction) in $\mathrm{N}_{2}$ between 285 and $446 \mathrm{~K}$, but acknowledge that the $T$ dependence might be erroneous due to the large scatter in their dataset.

The $\mathrm{NO}_{2}$ LIF signals obtained at low temperatures $(218$ and $234 \mathrm{~K})$ show deviation from linearity as expected if significant amounts of $\mathrm{NO}_{2}$ dimerize to $\mathrm{N}_{2} \mathrm{O}_{4}$. In Fig. 4 we plot the expected dependence of the LIF signal from $\mathrm{NO}_{2}$ in the cold reactor on the ex situ $\mathrm{NO}_{2}$ concentration as calculated using Eq. (2) and the equilibrium constant $K_{8}$ recommended by IUPAC (solid lines) or NASA (dashed lines). The predicted dependence reproduces the measurements within $\sim 20 \%$ confirming that the literature values of equilibrium coefficient are appropriate for correcting $\mathrm{NO}_{2}$ concentrations in kinetic experiments at low temperatures. As our LIF signals at low temperatures lie broadly between those predicted using the equilibrium constants preferred by IUPAC and NASA, we have used an average value of $K_{8}$ for correcting $\mathrm{NO}_{2}$ concentrations in the kinetic experiments. We note here that the corrections applied are small and do not impact significantly on the accuracy of the rate coefficient we derive (see later for details). 


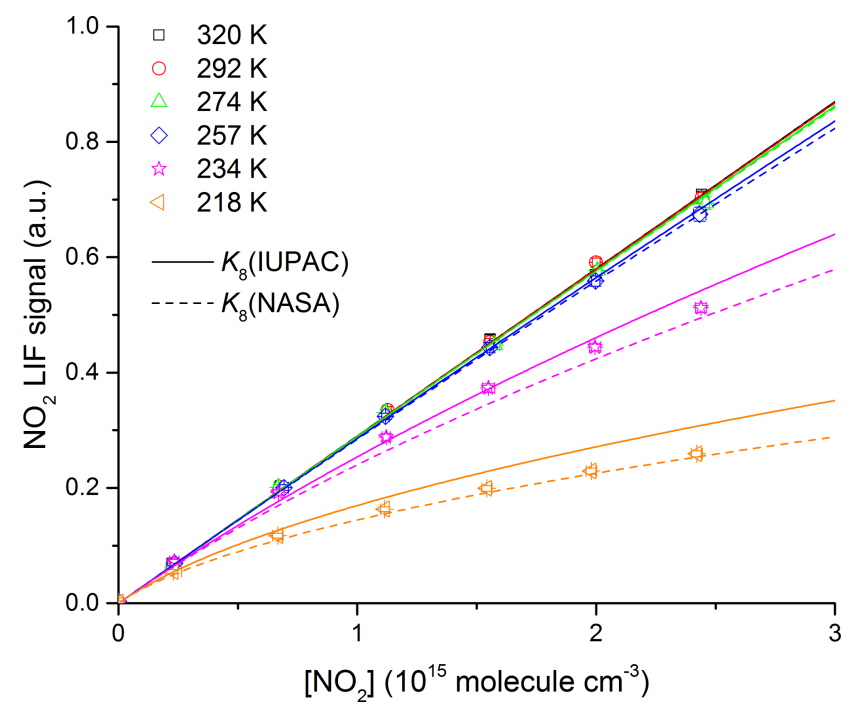

Figure 4. $\mathrm{NO}_{2}$ LIF signal (following excitation at $564 \mathrm{~nm}$ ) as a function of $\mathrm{NO}_{2}$ concentration at six different temperatures from 218 to $320 \mathrm{~K}$. The experiments were performed in $\mathrm{N}_{2}$ bath gas $\left(\left[\mathrm{N}_{2}\right]=1.65 \times 10^{18}\right.$ molecule $\left.\mathrm{cm}^{-3}\right)$. The lines were derived using the equilibrium constants $\left(K_{8}\right)$ for $\mathrm{NO}_{2}$ dimerization to $\mathrm{N}_{2} \mathrm{O}_{4}$ preferred by IUPAC (solid lines) and NASA (dashed lines).

\subsection{Rate coefficients for $\mathrm{OH}+\mathrm{NO}_{2}\left(k_{5}\right)$}

In this section, we present our measurements of $k_{5}$ in $\mathrm{N}_{2}$ and $\mathrm{O}_{2}$ bath gases and compare the results to previous datasets and the parameterizations presently preferred by evaluation panels. The PLP-LIF studies were carried out under pseudo first-order conditions with $\left[\mathrm{NO}_{2}\right] \gg[\mathrm{OH}]$, so that the $\mathrm{OH}$ profiles are described by

$[\mathrm{OH}]_{t}=[\mathrm{OH}]_{0} \exp \left(-k^{\prime} t\right)$,

where $[\mathrm{OH}]_{t}$ is the concentration (molecule $\mathrm{cm}^{-3}$ ) at time $t$ after the laser pulse. $k^{\prime}$ is the pseudo-first-order rate coefficient and is defined as

$k^{\prime}=k_{5}\left[\mathrm{NO}_{2}\right]+k_{\mathrm{d}}$,

where $k_{5}$ is the bimolecular rate coefficient $\left(\mathrm{cm}^{3}\right.$ molecule $\left.{ }^{-1} \mathrm{~s}^{-1}\right)$ for the reaction between $\mathrm{OH}$ and $\mathrm{NO}_{2} . k_{\mathrm{d}}\left(\mathrm{s}^{-1}\right)$ accounts for $\mathrm{OH}$ loss due to diffusion out of the reaction zone and reaction with $\mathrm{HNO}_{3}$ or $\mathrm{H}_{2} \mathrm{O}_{2}$. Figures 5 and 6 display representative datasets obtained in $\mathrm{N}_{2}$ bath gas at $295 \mathrm{~K}$ and at four different pressures (100, 300,500 , and 900 Torr). $\mathrm{OH}$ decays are exponential over $>2$ orders of magnitude and the plots of $k^{\prime}$ versus $\left[\mathrm{NO}_{2}\right]$ are straight lines as expected from Eq. (4). Values of $k_{5}$ derived from these datasets typically have statistical uncertainty $(2 \sigma)$ of less than $5 \%$.

The overall uncertainty in $k_{5}$ is dominated by uncertainty in the $\mathrm{NO}_{2}$ concentration, the origin of which is uncertainty in the $\mathrm{NO}_{2}$ absorption cross sections and in the correction for

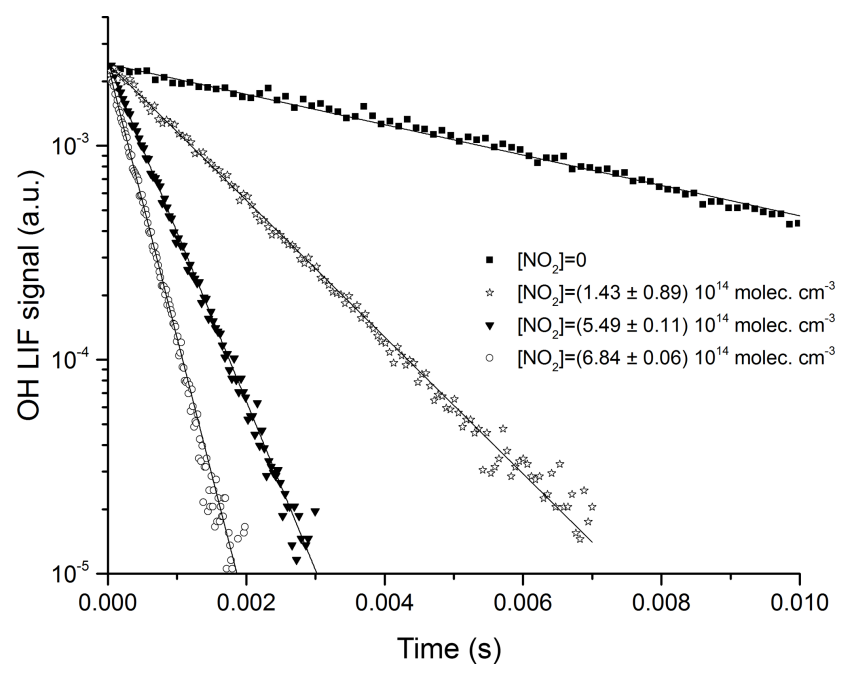

Figure 5. Exponential decay of the $\mathrm{OH}$ LIF signal in 100 Torr $\mathrm{N}_{2}$, at $293 \mathrm{~K}$, and at four different $\mathrm{NO}_{2}$ concentrations. $\mathrm{OH}$ was generated by the photolysis (at time $=0 \mathrm{~s}$ ) of $\mathrm{H}_{2} \mathrm{O}_{2}$ at $248 \mathrm{~nm}$. The solid lines are fits to the datasets using Eq. (3).

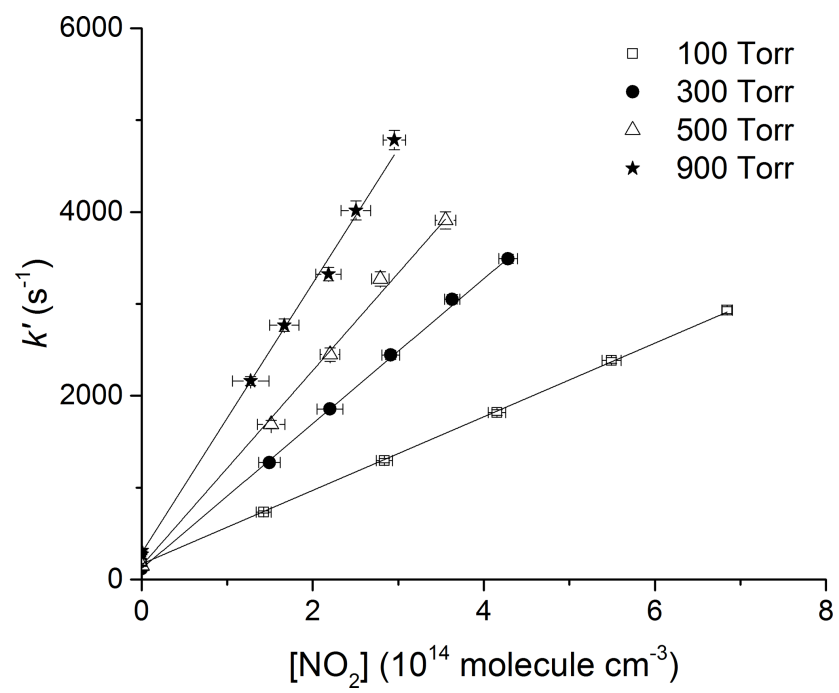

Figure 6. Plots of $k^{\prime}$ versus $\left[\mathrm{NO}_{2}\right]$ at four different pressures in $\mathrm{N}_{2}$ and at $295 \mathrm{~K}$. The lines are least-squares fits to the data using Eq. (4). Error bars are $2 \sigma$ statistical only.

$\mathrm{NO}_{2}$ dimerization to $\mathrm{N}_{2} \mathrm{O}_{4}$. The $\mathrm{NO}_{2}$ concentration used to determine the rate coefficient was the average of those determined by analysing the optical density between 405 and $450 \mathrm{~nm}$ in the $110 \mathrm{~cm}$ absorption cell located upstream of the reactor and the optical density at $365 \mathrm{~nm}$ measured in the $43.8 \mathrm{~nm}$ optical absorption cell located downstream of the reactor. The two concentrations generally agreed to better than $2 \%$. The optical absorption measurements of $\mathrm{NO}_{2}$ were made at room temperature. However, when the reactor is operated at low temperatures some $\mathrm{NO}_{2}$ is converted to $\mathrm{N}_{2} \mathrm{O}_{4}$ via the equilibrium (R8) and a correction must be 
made to account for the difference in $\left[\mathrm{NO}_{2}\right]$ between the optical absorption measurement and that present in the reactor (see Sect. 3.1.4). At temperatures above $273 \mathrm{~K}$, no correction to $\left[\mathrm{NO}_{2}\right]$ was necessary, but amounted to $0.5 \%$ to $3.5 \%$ at $245 \mathrm{~K}, 4 \%$ to $26 \%$ at $229 \mathrm{~K}$ and $6 \%$ to $29 \%$ at $217 \mathrm{~K}$, with the largest corrections being associated with the highest $\mathrm{NO}_{2}$ concentrations. The total uncertainty associated with each value of $k_{5}$ is listed in Table 1 and considers uncertainty in $\mathrm{NO}_{2}$ concentration measurement (i.e. uncertainty associated with $\mathrm{NO}_{2}$ cross sections and the equilibrium constant for $\mathrm{NO}_{2}$ dimerization) as well as statistical error on the fits to derive $k^{\prime}$ (Fig. 6). The expression used to calculate the total overall uncertainty for each value of $k_{5}$ is given in the Supplement and results in $\sim 8 \%$ at $T>240 \mathrm{~K}$ and $\sim 16 \%$ for measurements at 217 and $229 \mathrm{~K}$.

Apart from the use of different $\mathrm{OH}$ precursors (values of $k_{5}$ derived when using photolysis of either $\mathrm{H}_{2} \mathrm{O}_{2}$ or $\mathrm{HNO}_{3}$ were not significantly different), experiments were carried out to investigate the effect of different initial $\mathrm{OH}$ concentrations. In two sets of experiments, at total pressures of either 200 or 500 Torr $\mathrm{N}_{2}$, the $248 \mathrm{~nm}$ laser fluence was varied by a factor of 7 (from $\sim 5$ to $35 \mathrm{~mJ} \mathrm{~cm}^{-2}$ ) and the $\mathrm{H}_{2} \mathrm{O}_{2}$ and $\mathrm{HNO}_{3}$ concentrations by 4 and 6 respectively, resulting (at 200 Torr) in a factor of 10 change in $[\mathrm{OH}]_{0}$ (from $\sim 10^{11}$ to $10^{12}$ molecule $\mathrm{cm}^{-3}$ ) (see Table 1 ). Reducing the laser repetition rate from 10 to $5 \mathrm{~Hz}$ had no discernible effect on the value of $k_{5}$ retrieved $\left(10.6 \pm 0.6 \times 10^{-12} \mathrm{~cm}^{3}\right.$ molecule ${ }^{-1} \mathrm{~s}^{-1}$ at $10 \mathrm{~Hz}$ and $10.7 \pm 0.1 \times 10^{-12} \mathrm{~cm}^{3}$ molecule ${ }^{-1} \mathrm{~s}^{-1}$ at $5 \mathrm{~Hz}$; see Table 1 , rate coefficients at $293 \mathrm{~K}$ and 498.5 Torr).

The results indicate that, within the range of $\mathrm{OH}$ mentioned above, there is no significant influence of secondary reactions of $\mathrm{OH}$ on the determination of $k_{5}$. For the $\mathrm{OH}+\mathrm{NO}_{2}$ reaction, the use of $\mathrm{OH}$ concentrations as high as $10^{12}$ molecule $\mathrm{cm}^{-3}$ is not expected to have a significant impact on the $\mathrm{OH}$ decay rates because the major product, $\mathrm{HNO}_{3}$, reacts only slowly with $\mathrm{OH}$, with $k\left(\mathrm{OH}+\mathrm{HNO}_{3}\right)=1.6 \times 10^{-13} \mathrm{~cm}^{3}$ molecule ${ }^{-1} \mathrm{~s}^{-1}$ at $296 \mathrm{~K}$ and 250 Torr (Dulitz et al., 2018). Even if the minor product, $\mathrm{HOONO}$, were to react with $\mathrm{OH}$ with a rate coefficient of $2 \times 10^{-10} \mathrm{~cm}^{3}$ molecule $\mathrm{e}^{-1} \mathrm{~s}^{-1}$ (i.e. close to collision frequency), this would still have an impact of less than $2 \%$ on the first-order $\mathrm{OH}$ decay rate coefficient at 750 Torr pressure.

The self-reaction of $\mathrm{OH}$ at an initial concentration of $1 \times 10^{12}$ molecule $\mathrm{cm}^{-3}$ results in a loss rate of $\sim 15 \mathrm{~s}^{-1}$, which is negligible compared to typical decay constants of $\sim 1000$ to $10000 \mathrm{~s}^{-1}$ due to reaction with $\mathrm{NO}_{2}$. Photolysis of $\mathrm{NO}_{2}$ is inefficient as the cross section of $\mathrm{NO}_{2}$ is low at $248 \mathrm{~nm}\left(1 \times 10^{-20} \mathrm{~cm}^{2}\right.$ molecule ${ }^{-1}$; IUPAC, 2019) but can result in approximately equivalent initial $\mathrm{O}\left({ }^{3} \mathrm{P}\right)$ and $\mathrm{OH}$ concentrations. However, the presence of $\mathrm{O}\left({ }^{3} \mathrm{P}\right)$ has a negligible impact as its fate is mainly reaction with $\mathrm{NO}_{2}$ to form $\mathrm{NO}$, which also reacts only slowly with $\mathrm{OH}$.
Table 1. Measurements of $k_{5}$ in $\mathrm{N}_{2}$ and $\mathrm{O}_{2}$ bath gases.

\begin{tabular}{|c|c|c|c|c|c|c|}
\hline$p^{\mathrm{a}}$ & $T^{\mathrm{b}}$ & $M^{\mathrm{c}}$ & $\begin{array}{l}\mathrm{OH} \\
\text { precursor }\end{array}$ & {$[\mathrm{OH}]_{0}^{\mathrm{d}}$} & $k_{5}^{\mathrm{e}}$ & $\begin{array}{r}{\left[\mathrm{NO}_{2}\right]} \\
\text { correction }\end{array}$ \\
\hline \multicolumn{7}{|c|}{$\mathrm{N}_{2}$ bath gas } \\
\hline 22.4 & \multirow{4}{*}{217} & 1.00 & $\mathrm{HNO}_{3}$ & 1.8 & $3.78 \pm 0.76$ & $12-24$ \\
\hline 39.7 & & 1.77 & $\mathrm{HNO}_{3}$ & 1.4 & $5.50 \pm 1.18$ & $6-22$ \\
\hline 56.2 & & 2.50 & $\mathrm{HNO}_{3}$ & 1.0 & $6.99 \pm 0.99$ & $8-16$ \\
\hline 78.8 & & 3.51 & $\mathrm{HNO}_{3}$ & 1.0 & $8.70 \pm 1.59$ & $6-29$ \\
\hline 12.3 & \multirow{6}{*}{229} & 0.52 & $\mathrm{HNO}_{3}$ & 2.3 & $1.84 \pm 0.43$ & $12-26$ \\
\hline 18.5 & & 0.78 & $\mathrm{HNO}_{3}$ & 3.7 & $2.62 \pm 0.39$ & 6-14 \\
\hline 38.5 & & 1.62 & $\mathrm{HNO}_{3}$ & 3.8 & $4.82 \pm 0.91$ & $8-18$ \\
\hline 79.5 & & 3.35 & $\mathrm{HNO}_{3}$ & 2.7 & $7.63 \pm 0.79$ & 4-14 \\
\hline 117.1 & & 4.94 & $\mathrm{HNO}_{3}$ & 4.2 & $9.18 \pm 1.10$ & $8-18$ \\
\hline 158.8 & & 6.66 & $\mathrm{HNO}_{3}$ & 5.4 & $11.0 \pm 1.23$ & $4-13$ \\
\hline 22.4 & \multirow{6}{*}{245} & 0.88 & $\mathrm{HNO}_{3}$ & 1.1 & $2.75 \pm 0.19$ & $0.5-3.5$ \\
\hline 44.9 & & 1.77 & $\mathrm{HNO}_{3}$ & 2.2 & $4.47 \pm 0.32$ & $0.9-2.8$ \\
\hline 63.7 & & 2.51 & $\mathrm{HNO}_{3}$ & 2.2 & $5.41 \pm 0.37$ & $0.5-3.2$ \\
\hline 84.4 & & 3.33 & $\mathrm{HNO}_{3}$ & 1.8 & $6.39 \pm 0.45$ & $0.5-3.5$ \\
\hline 122.8 & & 4.84 & $\mathrm{HNO}_{3}$ & 1.5 & $8.01 \pm 0.72$ & $0.8-2.5$ \\
\hline 165 & & 6.50 & $\mathrm{HNO}_{3}$ & 2.7 & $9.60 \pm 0.82$ & $0.9-2.8$ \\
\hline 100.4 & 273 & 3.53 & $\mathrm{H}_{2} \mathrm{O}_{2}$ & 8.7 & $5.07 \pm 0.36$ & 0 \\
\hline 12.3 & \multirow{34}{*}{293} & 0.41 & $\mathrm{HNO}_{3}$ & 5.5 & $0.96 \pm 0.07$ & 0 \\
\hline 13.3 & & 0.44 & $\mathrm{H}_{2} \mathrm{O}_{2}$ & 2.5 & $0.98 \pm 0.16$ & 0 \\
\hline 20.1 & & 0.66 & $\mathrm{H}_{2} \mathrm{O}_{2}$ & 3.4 & $1.34 \pm 0.09$ & 0 \\
\hline 25.5 & & 0.84 & $\mathrm{H}_{2} \mathrm{O}_{2}$ & 1.9 & $1.66 \pm 0.12$ & 0 \\
\hline 26.4 & & 0.87 & $\mathrm{H}_{2} \mathrm{O}_{2}$ & 13.3 & $1.65 \pm 0.12$ & 0 \\
\hline 36.8 & & 1.22 & $\mathrm{H}_{2} \mathrm{O}_{2}$ & 2.3 & $2.11 \pm 0.13$ & 0 \\
\hline 50.2 & & 1.65 & $\mathrm{H}_{2} \mathrm{O}_{2}$ & 6.2 & $2.58 \pm 0.16$ & 0 \\
\hline 56.8 & & 1.88 & $\mathrm{H}_{2} \mathrm{O}_{2}$ & 3.7 & $2.88 \pm 0.19$ & 0 \\
\hline 75.6 & & 2.50 & $\mathrm{H}_{2} \mathrm{O}_{2}$ & 2.0 & $3.41 \pm 0.21$ & 0 \\
\hline 99.3 & & 3.25 & $\mathrm{H}_{2} \mathrm{O}_{2}$ & 5.8 & $3.90 \pm 0.35$ & 0 \\
\hline 99.9 & & 3.28 & $\mathrm{H}_{2} \mathrm{O}_{2}$ & 5.2 & $4.05 \pm 0.25$ & 0 \\
\hline 102.3 & & 3.37 & $\mathrm{HNO}_{3}$ & 14.3 & $4.14 \pm 0.29$ & 0 \\
\hline 131.6 & & 4.35 & $\mathrm{H}_{2} \mathrm{O}_{2}$ & 1.7 & $4.98 \pm 0.33$ & 0 \\
\hline 133.3 & & 4.41 & $\mathrm{H}_{2} \mathrm{O}_{2}$ & 1.6 & $5.07 \pm 0.36$ & 0 \\
\hline 160.5 & & 5.31 & $\mathrm{H}_{2} \mathrm{O}_{2}$ & 1.6 & $5.69 \pm 0.40$ & 0 \\
\hline 199.8 & & 6.52 & $\mathrm{H}_{2} \mathrm{O}_{2}$ & 4.6 & $6.19 \pm 0.52$ & 0 \\
\hline 199.9 & & 6.56 & $\mathrm{HNO}_{3}$ & 11.3 & $6.12 \pm 0.42$ & 0 \\
\hline 200.8 & & 6.59 & $\mathrm{HNO}_{3}$ & 1.1 & $6.69 \pm 0.49$ & 0 \\
\hline 250.4 & & 8.27 & $\mathrm{H}_{2} \mathrm{O}_{2}$ & 3.4 & $7.26 \pm 0.46$ & 0 \\
\hline 299.4 & & 9.82 & $\mathrm{HNO}_{3}$ & 10.7 & $7.80 \pm 0.55$ & 0 \\
\hline 299.5 & & 9.82 & $\mathrm{H}_{2} \mathrm{O}_{2}$ & 3.9 & $8.02 \pm 0.55$ & 0 \\
\hline 299.5 & & 9.81 & $\mathrm{HNO}_{3}$ & 11.7 & $8.43 \pm 1.18$ & 0 \\
\hline 401 & & 13.20 & $\mathrm{HNO}_{3}$ & 11.2 & $9.23 \pm 0.86$ & 0 \\
\hline 401.3 & & 13.20 & $\mathrm{H}_{2} \mathrm{O}_{2}$ & 3.8 & $9.71 \pm 0.84$ & 0 \\
\hline 498.5 & & 16.30 & $\mathrm{H}_{2} \mathrm{O}_{2}$ & 7.3 & $10.6 \pm 0.87$ & 0 \\
\hline 498.5 & & 16.30 & $\mathrm{H}_{2} \mathrm{O}_{2}$ & 7.6 & $10.7 \pm 0.66^{\mathrm{g}}$ & 0 \\
\hline 498.7 & & 16.40 & $\mathrm{HNO}_{3}$ & 15.3 & $11.1 \pm 0.72$ & 0 \\
\hline 498.8 & & 16.40 & $\mathrm{H}_{2} \mathrm{O}_{2}$ & 4.5 & $11.0 \pm 0.73$ & 0 \\
\hline 598.8 & & 19.70 & $\mathrm{H}_{2} \mathrm{O}_{2}$ & 5.1 & $11.4 \pm 1.09$ & 0 \\
\hline 603.1 & & 19.80 & $\mathrm{HNO}_{3}$ & 15.9 & $12.2 \pm 0.76$ & 0 \\
\hline 705.5 & & 23.20 & $\mathrm{H}_{2} \mathrm{O}_{2}$ & 4.9 & $13.6 \pm 1.36$ & 0 \\
\hline 709.6 & & 23.30 & $\mathrm{HNO}_{3}$ & 11.6 & $12.9 \pm 1.10$ & 0 \\
\hline 796.7 & & 26.20 & $\mathrm{H}_{2} \mathrm{O}_{2}$ & 10.0 & $13.3 \pm 1.11$ & 0 \\
\hline 901.1 & & 29.50 & $\mathrm{H}_{2} \mathrm{O}_{2}$ & 10.3 & $14.8 \pm 1.34$ & 0 \\
\hline 115.6 & \multirow{4}{*}{333} & 3.35 & $\mathrm{H}_{2} \mathrm{O}_{2}$ & 9.9 & $2.91 \pm 0.21$ & 0 \\
\hline 342.3 & & 9.93 & $\mathrm{H}_{2} \mathrm{O}_{2}$ & 4.5 & $6.67 \pm 0.48$ & 0 \\
\hline 569.9 & & 16.52 & $\mathrm{H}_{2} \mathrm{O}_{2}$ & 5.2 & $8.88 \pm 0.82$ & 0 \\
\hline 794.6 & & 23.04 & $\mathrm{H}_{2} \mathrm{O}_{2}$ & 5.1 & $10.15 \pm 1.13$ & 0 \\
\hline
\end{tabular}


Table 1. Continued.

\begin{tabular}{lcllllr}
\hline$p^{\mathrm{a}}$ & $T^{\mathrm{b}}$ & $M^{\mathrm{c}}$ & $\begin{array}{l}\mathrm{OH} \\
\text { precursor }\end{array}$ & {$[\mathrm{OH}]_{0}^{\mathrm{d}}$} & $k_{5}^{\mathrm{e}}$ & $\begin{array}{r}{\left[\mathrm{NO}_{2}\right]} \\
\text { correction }\end{array}$ \\
\hline $\mathrm{O}_{2}$ bath gas & & & & & \\
\hline 99.2 & & 3.25 & $\mathrm{H}_{2} \mathrm{O}_{2}$ & 24.5 & $3.31 \pm 0.29$ & 0 \\
50.2 & 1.64 & $\mathrm{H}_{2} \mathrm{O}_{2}$ & 13.7 & $2.16 \pm 0.16$ & 0 \\
202.3 & 293 & 6.64 & $\mathrm{H}_{2} \mathrm{O}_{2}$ & 25.7 & $5.47 \pm 0.43$ & 0 \\
150.7 & & 4.94 & $\mathrm{H}_{2} \mathrm{O}_{2}$ & 17.9 & $4.50 \pm 0.33$ & 0 \\
250.6 & 8.22 & $\mathrm{H}_{2} \mathrm{O}_{2}$ & 18.1 & $6.03 \pm 0.39$ & 0 \\
\hline
\end{tabular}

${ }^{a}$ In torr. ${ }^{\mathrm{b}}$ In kelvin. ${ }^{\mathrm{c}}$ In $10^{18}$ molecules per cubic centimetre. ${ }^{\mathrm{d}}$ In $10^{11}$ molecules per cubic centimetre, the $\mathrm{OH}$ concentration was calculated from the $248 \mathrm{~nm}$ laser fluence, $\mathrm{H}_{2} \mathrm{O}_{2}$ or $\mathrm{HNO}_{3}$ concentrations and the respective quantum yield for $\mathrm{OH}$ production. ${ }^{\mathrm{e}}$ In $10^{-12} \mathrm{cubic}$ centimetres per molecule per second (errors are total uncertainty, $2 \sigma$ ). ${ }^{\mathrm{f}}$ As a percentage; due to dimerization of $\mathrm{NO}_{2}$ to $\mathrm{N}_{2} \mathrm{O}_{4}$, which is insignificant at temperatures $>273 \mathrm{~K}$. ${ }^{\mathrm{g}}$ Experiment performed at a laser repetition rate of $5 \mathrm{~Hz}$ (instead of the usual $10 \mathrm{~Hz}$ ).

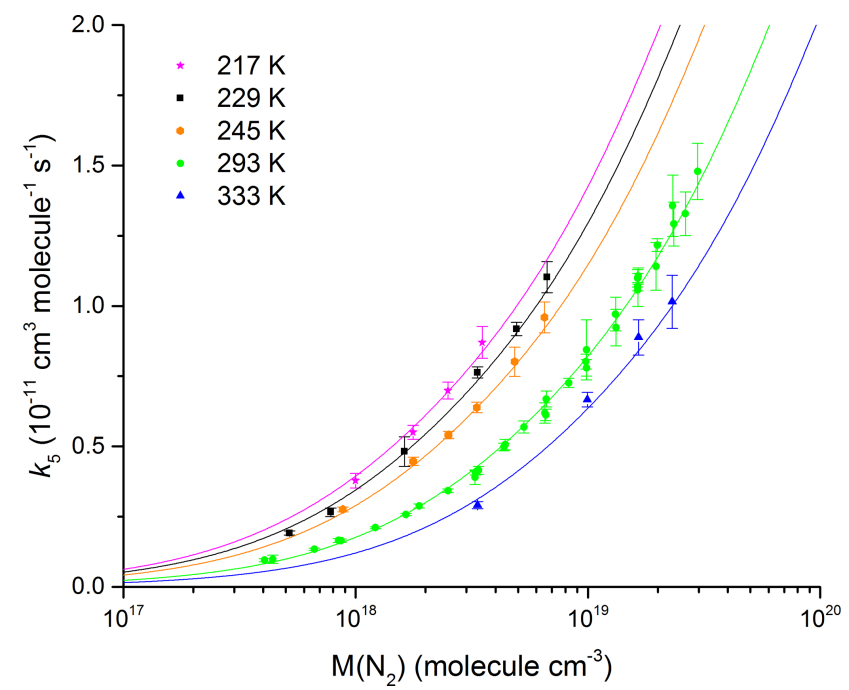

Figure 7. Rate coefficient, $k_{5}$, as a function of $\mathrm{N}_{2}$ density in the falloff range for five different temperatures. The error bars represent $2 \sigma$ statistical uncertainty. The solid line fits to the data are described by Eq. (5) with $k_{0}=2.6 \times 10^{-30} \mathrm{~cm}^{6}$ molecule ${ }^{-2} \mathrm{~s}^{-1}, m=3.6, n=0$, $k_{\infty}=6.3 \times 10^{-11} \mathrm{~cm}^{3}$ molecule ${ }^{-1} \mathrm{~s}^{-1}$, and $F_{\mathrm{c}}=0.39$ (fixed).

\subsubsection{Measurements of $k_{5}$ in $\mathrm{N}_{2}$ bath gas and comparison with literature}

Our measurements of $k_{5}$ in $\mathrm{N}_{2}$ bath gas (12-900 Torr, 217$333 \mathrm{~K}$ ) are summarized in Fig. 7 and listed in Table 1.

The solid lines in Fig. 7 are fits according to the Troe formalism for termolecular reactions (Troe, 1983) as adopted by the IUPAC panel:

$k_{5}(p, T)=\frac{\beta k_{0}\left(\frac{T}{300}\right)^{-m} M k_{\infty}\left(\frac{T}{300}\right)^{-n}}{\beta k_{0}\left(\frac{T}{300}\right)^{-m} M+k_{\infty}\left(\frac{T}{300}\right)^{-n}} \log F$,

where $k_{0}$ is the low-pressure limit rate coefficient in $\mathrm{cm}^{6}$ molecule ${ }^{-2} \mathrm{~s}^{-1}, k_{\infty}$ is the high-pressure limit rate coefficient in $\mathrm{cm}^{3}$ molecule ${ }^{-1} \mathrm{~s}^{-1}, T$ is the temperature in kelvin, $M$ is the density in molecules per cubic metre, and $m$ and $n$ are dimensionless temperature exponents. $\beta$ takes into ac- count the overall collision efficiency for energy transfer from the initially formed $\mathrm{OH}-\mathrm{NO}_{2}$ association complex to the bath gases, with

$\beta=\sum \beta_{i} x_{i}$,

where $\beta_{i}$ and $x_{i}$ are the collision efficiency and the mixing ratio of bath gas $i$ respectively.

The broadening factor, $F$, is defined as

$$
\log F=\frac{\log F_{\mathrm{c}}}{1+\left[\log \left(\frac{\beta k_{0}\left(\frac{T}{300}\right)^{-m} M}{k_{\infty}\left(\frac{T}{300}\right)^{-n}}\right) / N\right]^{2}},
$$

where $N=\left[0.75-1.27 \log F_{\mathrm{c}}\right]$ and $F_{\mathrm{c}}$ is the broadening factor at the centre of the fall-off curve.

Accurate representation of termolecular rate coefficients using this expression requires data on the low- and highpressure limiting rate coefficients, $k_{0}$ and $k_{\infty}$, and their temperature dependence. Data close to the low-pressure limit have generally been obtained using low-pressure flow tubes (Howard, 1979; Keyser, 1984), whereas measurements close to the high-pressure limit required equipment capable of operation at several hundred bar or the use of a different approach in which the rate coefficient for relaxation of vibrationally excited $\mathrm{OH}$ in collision with $\mathrm{NO}_{2}$ is equated to the high-pressure limit of the association reaction.

In the case of the title reaction, several measurements have been performed close to the low-pressure limit ( 0.5 to 10 Torr) (Anderson and Kaufman, 1972; Anderson et al., 1974; Anderson, 1980; Burrows et al., 1983; Howard and Evenson, 1974), while only one group has carried out experiments at pressures approaching the high-pressure limit (Hippler et al., 2002, 2006). Even at 500 bar He, the reaction of $\mathrm{OH}$ with $\mathrm{NO}_{2}$ is still not at the high-pressure limit, and at pressures as low as 10 Torr of He, there is already evidence for significant fall-off. The two determinations (D'Ottone et al., 2005; Smith and Williams, 1985) of the rate constant for vibrational relaxation of $\mathrm{OH}$ in collision with $\mathrm{NO}_{2}$ deviate in their value of $k_{\infty}$ by $\sim 25 \%$. For many termolecular reactions, limitations in data quality mean that $k_{0}$ or $k_{\infty}$ is often derived by fitting to multiple datasets that span a large range of pressures and fixing $F_{\mathrm{c}}$ to either a theoretical value (IUPAC, 2019) or to a value of 0.6 (Burkholder et al., 2015). To analyse our data we used a similar approach to that of IUPAC with the broadening factor fixed to 0.39 (Cobos and Troe, 2003). In order to further reduce the number of variables when fitting data to expression (Eq. 7) we also make the assumption that $k_{\infty}$ is independent of temperature $(n=0)$. This assumption is reasonable as the value of $n$ is expected to be much smaller than that of $m$ and the data at high pressures are not of sufficient quality to constrain this parameter.

By fitting our data $(217,229,245,273,293$, and $333 \mathrm{~K})$ to expression (Eq. 7) and allowing $k_{0}, m$, and $k_{\infty}$ to vary, we derive values of $k_{0}=2.6 \times 10^{-30} \mathrm{~cm}^{6}$ molecule ${ }^{-2} \mathrm{~s}^{-1}$, 
$k_{\infty}=6.3 \times 10^{-11} \mathrm{~cm}^{3}$ molecule ${ }^{-1} \mathrm{~s}^{-1}$, and $m=3.6$. These parameters accurately reproduce the pressure and temperature dependence of $k_{5}$, which we observe in $\mathrm{N}_{2}$ bath gas (see Fig. 7) with most of the individual rate coefficients measured agreeing to better than $5 \%$ of the parametrization. This is highlighted in Fig. S2, which shows the percentage deviation of each data point from the value derived using the values of $k_{0}, k_{\infty}, n, m$, and $F_{\mathrm{c}}$ listed above.

We now compare our value of $k_{0}$ to those reported from low-pressure flow-tube studies of the title reaction. We note that, in low-pressure flow tubes operated at pressures greater than a few torr of $\mathrm{N}_{2}$, mixing effects and $\mathrm{OH}$ losses to walls severely impede accurate kinetic measurements of $\mathrm{OH}$ rate coefficients, especially at low temperatures (Brown, 1978; Howard, 1979). In their study of the reaction between $\mathrm{OH}$ and $\mathrm{NO}_{2}$, Howard and Evenson (1974) do not report rate coefficients at pressures greater than 2 Torr $\mathrm{N}_{2}$ because of the large uncertainty resulting from the corrections applied. In low-pressure flow-tube studies of the $\mathrm{OH}+\mathrm{NO}_{2}$ reaction, the loss rate constant for $\mathrm{OH}\left(k^{\prime}\right)$ is a composite term (Eq. 8), with contributions from the association reaction $\left(k_{5}\left[\mathrm{NO}_{2}\right]\right.$, slow at low pressures), the loss of $\mathrm{OH}$ to the bare flow-tube wall $\left(k_{\mathrm{w}}\right.$, experimentally derived in the absence of $\left.\mathrm{NO}_{2}\right)$, and the heterogeneous loss of $\mathrm{OH}$ due to reaction with surfaceadsorbed $\mathrm{NO}_{2}\left(k_{\mathrm{S}}\left[\mathrm{NO}_{2}\right]_{\mathrm{S}}\right)$, which depends on the rate coefficient for the surface reaction $\left(k_{\mathrm{s}}\right)$ and the availability of surface-adsorbed $\mathrm{NO}_{2}\left(\left[\mathrm{NO}_{2}\right]_{\mathrm{S}}\right)$, with the latter dependent in a non-linear manner (via a gas-surface partition coefficient) on the gas-phase $\mathrm{NO}_{2}$ concentration.

$k^{\prime}=k_{5}\left[\mathrm{NO}_{2}\right]+k_{\mathrm{w}}+k_{\mathrm{s}}\left[\mathrm{NO}_{2}\right]_{\mathrm{s}}$

In low-pressure flow-tube studies, correction is rarely made for the surface-reaction-induced heterogeneous loss of $\mathrm{OH}$, in this case $k_{\mathrm{s}}\left[\mathrm{NO}_{2}\right]_{\mathrm{s}}$, the manifestation of which is often a positive intercept in plots of $k_{\mathrm{bi}}$ as a function of molecular density (Anderson et al., 1974; Howard and Evenson, 1974).

For the reaction of $\mathrm{OH}+\mathrm{NO}_{2}$ in $\mathrm{N}_{2}$, low-pressure flowtube studies report values of $k_{0}$ between 2.0 and $2.9 \times$ $10^{-30} \mathrm{~cm}^{6}$ molecule $\mathrm{s}^{-2}$ close to room temperature. Although this range is consistent with the value we derive $\left(2.6 \times 10^{-30} \mathrm{~cm}^{6}\right.$ molecule $\left.\mathrm{s}^{-2}\right)$, the agreement is to some extent fortuitous for reasons outlined above and also because the low-pressure flow-tube studies of the reaction between $\mathrm{OH}$ and $\mathrm{NO}_{2}$ report values of $k_{0}$ that were derived by assuming a linear dependence of the rate coefficient on pressure. Our precise dataset and the parameterization with broad fall-off behaviour indicate significant deviation from linear behaviour at pressures of 2 Torr of $\mathrm{N}_{2}$. In order to estimate the size of the error made by assuming linear behaviour, we calculated rate coefficients for the pressure range of 0.5 to 10 Torr of $\mathrm{N}_{2}$ using fall-off curves with $F_{\mathrm{c}}=0.39, k_{0}=2.6 \times 10^{-30} \mathrm{~cm}^{6}$ molecule $\mathrm{s}^{-2}$ and $k_{\infty}=6.3 \times 10^{-11} \mathrm{~cm}^{3}$ molecule $\mathrm{s}^{-1} \mathrm{~s}^{-1}$. Unweighted linear fitting of the rate coefficients thus obtained resulted in

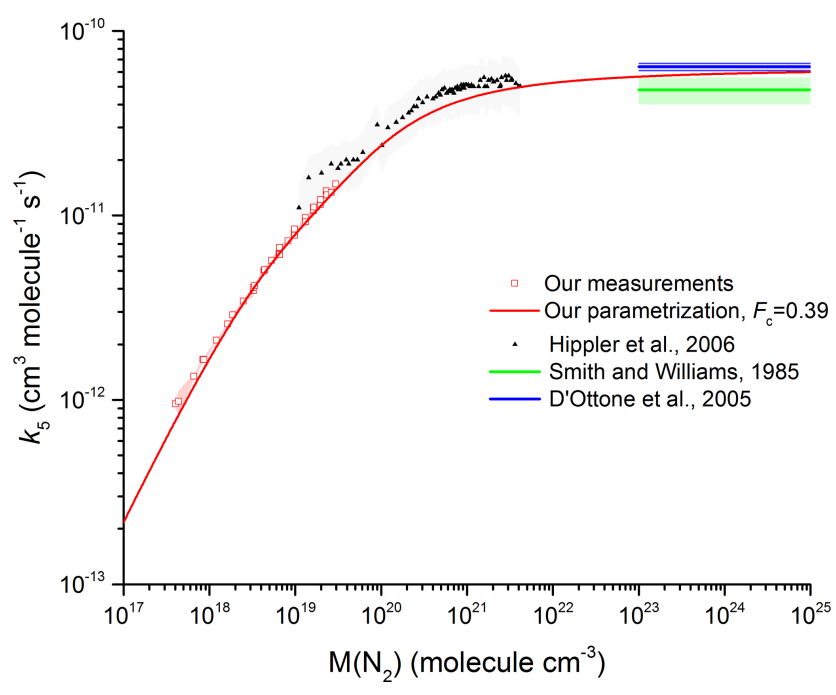

Figure 8. Comparison between our results in $\mathrm{N}_{2}$ with the measurements by Hippler et al. (2006) (He bath gas; the grey shaded area represents total uncertainty) and the high-pressure limits derived by Smith and Williams (1985) and D'Ottone et al. (2005). All measurements are close to $298 \mathrm{~K}$. The red line was obtained using Eq. (5) with $k_{0}=2.6 \times 10^{-30} \mathrm{~cm}^{6}$ molecule ${ }^{-2} \mathrm{~s}^{-1}, m=3.6, n=0$, $k_{\infty}=6.3 \times 10^{-11} \mathrm{~cm}^{3}$ molecule ${ }^{-1} \mathrm{~s}^{-1}$, and $F_{\mathrm{c}}=0.39$ (fixed).

a value of $k_{0}=2.3 \times 10^{-30} \mathrm{~cm}^{6}$ molecule ${ }^{-2} \mathrm{~s}^{-1}$, an underestimation of $15 \%$ (when fitted up to 2 Torr), which increases to $25 \%$ when the fit is extended to 10 Torr. The values of $k_{0}$ obtained in the low-pressure flow-tube studies are thus likely to be biased to lower values, especially those that extend to pressures above 2 Torr $\mathrm{N}_{2}$, though the effects of fall-off may not be evident in the highly scattered original datasets. The two low-pressure flow-tube studies (Anderson, 1980; Howard and Evenson, 1974) (both up to 2 Torr $\mathrm{N}_{2}$ ) that reported rate coefficients at various pressures and the value of $k_{0}$ derived are compared to our parameterization in Fig. S3. The data of Anderson (1980) are limited in number and display large scatter. The reported value (at $300 \mathrm{~K}$ ) of $k_{0}=2.3 \times 10^{-30} \mathrm{~cm}^{6}$ molecule ${ }^{-2} \mathrm{~s}^{-1}$ appears to have been obtained from a linear fit with the intercept fixed to zero. The original rate coefficients by Howard and Evenson (1974) display better precision, but indicate a large intercept at zero pressure of $1.8 \times 10^{-14} \mathrm{~cm}^{3}$ molecule $\mathrm{s}^{-1} \mathrm{~s}^{-1}$. The data simply corrected by subtracting a pressure-independent offset still lie $\sim 20 \%$ above our parametrization. We conclude that the low-pressure flow-tube studies of the rate coefficient for $\mathrm{OH}+\mathrm{NO}_{2}$ are not of sufficient precision or accuracy to define $k_{0}$ for the purpose of obtaining an accurate parameterization of the rate coefficient, $k_{5}$.

We now compare our value of $k_{\infty}(6.3 \times$ $10^{-11} \mathrm{~cm}^{3}$ molecule $\mathrm{s}^{-1}$ ) to literature values. Figure 8 shows our data at $293 \mathrm{~K}$ (open symbols) along with values of $k_{\infty}$ (blue- and green-shaded areas) derived from the vibrational relaxation of $\mathrm{OH}$ (D'Ottone et al., 2005; 
Smith and Williams, 1985). The height of the shaded areas indicates the reported overall uncertainty. We also plot the rate coefficients of Hippler et al. (2006) obtained at high pressure in He. To compare our measurements in $\mathrm{N}_{2}$ with the high-pressure data in $\mathrm{He}$, we scaled the He pressure by a factor of 0.39 (determined in our laboratory). We recognize that this is not a rigorous treatment of the relative collision efficiency of $\mathrm{N}_{2}$ and $\mathrm{He}$ data close to the high-pressure limit, but note that using a more complex approach (i.e. using a density-dependent correction and bath-gas-dependent values of $F_{\mathrm{c}}$ ) would lead to only insignificant changes in the equivalent $\mathrm{N}_{2}$ pressure. The solid red line is our parameterization with the values of $k_{0}, k_{\infty}$, and $F_{\mathrm{c}}$ given above and is seen to reproduce the trend in $k_{5}$ with pressure between $16 \mathrm{mbar}$ and $190 \mathrm{bar} \mathrm{N}_{2}$. Our value for $k_{\infty}$ of $(6.3 \pm 0.4) \times 10^{-11} \mathrm{~cm}^{3}$ molecule ${ }^{-1} \mathrm{~s}^{-1}$ (error given at $2 \sigma$ statistical only) is consistent within combined uncertainty with those of $(6.4 \pm 0.3) \times 10^{-11} \mathrm{~cm}^{3}$ molecule ${ }^{-1} \mathrm{~s}^{-1}$ obtained by D'Ottone et al. (2005) and $(4.8 \pm 0.8) \times$ $10^{-11} \mathrm{~cm}^{3}$ molecule $\mathrm{s}^{-1}$ obtained by Smith and Williams (1985).

In this section, we compare our values of $k_{0}$ and $k_{\infty}$ to those obtained in previous experiments at pressures in the fall-off regime, in which $\mathrm{OH}$ was generated photolytically. First, we note that values of $k_{0}$ and $k_{\infty}$ and $m$ obtained by fitting pressure-dependent datasets are strongly dependent on the choice of $F_{\mathrm{c}}$ and (to a lesser extent) whether an asymmetric (IUPAC) or symmetric (NASA) broadening factor has been used. In order to make a meaningful comparison between our values of $k_{0}, k_{\infty}$, and $m$ and those previously reported in the literature, we have therefore re-fitted the existing datasets using Eq. (5) with $F_{\mathrm{c}}$ fixed to 0.39. The results, presented in Table 2, show a variation of larger than a factor of 2 for both $k_{0}\left(1.8\right.$ to $3.8 \times 10^{-30} \mathrm{~cm}^{6}$ molecule $\left.{ }^{-2} \mathrm{~s}^{-1}\right)$ and $k_{\infty}\left(3.4\right.$ to $7.9 \times 10^{-11} \mathrm{~cm}^{3}$ molecule $\left.{ }^{-1} \mathrm{~s}^{-1}\right)$ even though similar experimental procedures were used. Our value of 3.60 for $m$ (describing the temperature dependence of $k_{0}$ ) is lower than those obtained from re-analysis of the datasets of Anastasi and Smith (1976), Wine et al. (1979), and Brown et al. (1999), which lie between 4.5 and 4.9. When the extensive dataset of Brown et al. (1999) is examined more closely, we find that excluding their room temperature data (the discrepancy at room temperature between our two works is discussed below) and only fit their four lowest temperatures (from 220 to $250 \mathrm{~K}$ ) we would obtain a $m$ of 3.9 , in agreement with our dataset. We note that the IUPAC and NASA evaluation panels recommend different values for $m$. While IUPAC have $m=4.5$ for both reaction channels, NASA suggest use of 3 and 3.9 for $\mathrm{HNO}_{3}$ and HOONO forming Reaction $\mathrm{R} 5 \mathrm{a}$ and $\mathrm{R} 5 \mathrm{~b}$ respectively.

In a series of figures (Figs. S4-S10), we compare values of $k_{5}$ derived from our parameterization with those presented in previous studies of $k_{5}$ in $\mathrm{N}_{2}$ bath gas over a similar pressure range. There are five previous flash/laser photolysis studies of the title reaction in $\mathrm{N}_{2}$ bath gas (Anastasi and
Table 2. Re-analysis of previous datasets using $F_{\mathrm{c}}=0.39$

\begin{tabular}{lcccrr}
\hline & $k_{0}^{\mathrm{a}, \mathrm{b}}$ & $m^{\mathrm{a}}$ & $k_{\infty}^{\mathrm{a}, \mathrm{c}}$ & $p$ (Torr) & $T(\mathrm{~K})$ \\
\hline This work & 2.6 & 3.6 & 6.3 & $12-900$ & $217-333$ \\
Anastasi and Smith (1976) & 3.4 & 4.7 & 3.4 & $10-500$ & $220-550$ \\
Wine et al. (1979) & 3.0 & 4.9 & 3.6 & $15-200$ & $247-352$ \\
Brown et al. (1999) & 2.3 & 4.5 & 4.8 & $20-250$ & $220-296$ \\
D'Ottone et al. (2001) & 3.8 & 0.3 & 3.8 & $30-700$ & $273-298$ \\
Hippler et al. (2006) & 2.5 & - & 7.3 & $600-147000$ & 298 \\
Mollner et al. (2010) & 1.8 & & 7.9 & $50-900$ & 298 \\
\hline
\end{tabular}

a Values listed may deviate from those previously reported owing to use of $F_{\mathrm{c}}=0.39$ to re-analyse data. ${ }^{b}$ Units are $10^{-30} \mathrm{~cm}^{6}$ molecule ${ }^{-2} \mathrm{~s}^{-1}$. ${ }^{c}$ Units are $10^{-11} \mathrm{~cm}^{3}$ molecule ${ }^{-1} \mathrm{~s}^{-1}$.

Smith, 1976; Brown et al., 1999; D’Ottone et al., 2001; Mollner et al., 2010; Wine et al., 1979). Three of these studies (Brown et al., 1999; D’Ottone et al., 2001; Wine et al., 1979) measured $\mathrm{NO}_{2}$ concentrations in situ at $365 \mathrm{~nm}$ using a cross section that deviated by less than $3 \%$ from that reported in the present study (see Sect. 3.1.3).

Anastasi and Smith (1976) reported values of $k_{5}$ (Fig. S4) over a wide range of temperatures $(220$ to $550 \mathrm{~K})$ and pressures (10 to 500 Torr) using flash photolysis of $\mathrm{H}_{2} \mathrm{O}$ or $\mathrm{HNO}_{3}$ as $\mathrm{OH}$ precursor with the detection of $\mathrm{OH}$ by resonance absorption. The $\mathrm{NO}_{2}$ concentration was obtained manometrically and no details pertaining to corrections for $\mathrm{NO}_{2}$ dimerization at low temperatures were given. Our parametrization reproduces most of their data within their experimental uncertainty (reported to be $36 \%$ at $2 \sigma$ ).

Wine et al. (1979) reported temperature-dependent values of $k_{5}$ (Fig. S5) in a more limited pressure range (up to $\sim 200$ Torr in $\mathrm{N}_{2}$ ) using laser photolysis of $\mathrm{HNO}_{3}$ to generate $\mathrm{OH}$ and resonance fluorescence to detect it. Our parameterization is in good agreement (better than $10 \%$ ) with most of their data apart from at higher pressures points where the difference is $>30 \%$ and greater than the combined quoted uncertainties.

Figure S6 compares our parameterization to the data of Brown et al. (1999) whose methods (PLP-LIF) were very similar to the present study. Their data are however limited to pressures of less than 250 Torr $\mathrm{N}_{2}$. At molecular densities of less than $\sim 7 \times 10^{18}$ molecule $\mathrm{cm}^{-3}$ there is good agreement ( $<10 \%$ deviation) but this increases to $\sim 20 \%$ at their highest pressures $\left(M=1 \times 10^{19}\right.$ molecule $\left.\mathrm{cm}^{-3}\right)$ and is largest at room temperature where it increases to $40 \%$. Compared to the present study, Brown et al. (1999) worked at lower concentrations of $\mathrm{NO}_{2}\left(<2 \times 10^{14}\right.$ molecule $\left.\mathrm{cm}^{-3}\right)$ in order to limit the formation of $\mathrm{N}_{2} \mathrm{O}_{4}$ at low temperatures. $\mathrm{N}_{2} \mathrm{O}_{4}$ formation is however not significant at $298 \mathrm{~K}$ and cannot explain the poor agreement at this temperature.

The dataset of D'Ottone et al. (2001) was also obtained using PLP-LIF and also covered a similar range of pressures (100 to 700 Torr $\mathrm{N}_{2}$ at 298 and $273 \mathrm{~K}$ ) to the present study. At room temperature, most of their measurements agree within $10 \%$ with our parameterization (Fig. S7); however their values for $k_{5}$ obtained at $273 \mathrm{~K}$ are consistently 
lower by $\sim 25 \%$. In fact, their measurements at 273 and $298 \mathrm{~K}$ are indistinguishable and thus do not display the temperature dependence observed by all previous studies

The most recent dataset (Mollner et al., 2010) was also obtained using PLP-LIF and covered pressures up to 900 Torr $\mathrm{N}_{2}$ at $298 \mathrm{~K}$. Mollner et al. (2010) monitored $\mathrm{NO}_{2}$ in situ via UV-visible broadband absorption using reference spectra from Vandaele et al. (2002) and Nizkorodov et al. (2004), though it is not clear how these two spectra were used or combined.

In Sect. 3.1.2, we indicated that using the spectra of Nizkorodov et al. (2004) that were obtained at pressures $>75$ Torr could lead to an overestimation of the $\mathrm{NO}_{2}$ concentration, which would result in an underestimation of $k_{5}$. We are unable to assess the extent to which this may have influenced the Mollner et al. (2010) values of $k_{5}$. On average, our parametrization overestimates their measurement of $k_{5}$ by $\sim 15 \%$ (Fig. S8).

Values of $k_{5}$ in the fall-off regime have also been obtained using a high-pressure laminar flow-tube set up (Donahue et al., 1997; Dransfield et al., 1999) with OH detection by LIF and $\mathrm{NO}_{2}$ concentrations derived by recording the concentration of a passive tracer $\left(\mathrm{CF}_{2} \mathrm{Cl}_{2}\right)$ using FTIR and UV absorption in mixtures of $\mathrm{NO}_{2}$ and $\mathrm{CF}_{2} \mathrm{Cl}_{2}$. Figures $\mathrm{S} 9$ and $\mathrm{S} 10$ indicate poor agreement between this dataset and our parameterization, the disagreement being most significant (factor 2) at room temperature. The discrepancy is smaller at low temperature with our parametrization predicting rates $\sim 5 \%$ to $25 \%$ faster in the 212.5 and $265 \mathrm{~K}$ temperature range.

The comparison of the various datasets reveals differences in the rate coefficients measured in $\mathrm{N}_{2}$ that cannot be easily explained. All studies worked under pseudo-first-order conditions. Any discrepancy in $k_{5}$ between two independent studies is most likely related to the accuracy with which the concentration of $\mathrm{NO}_{2}$ was measured, with secondary chemistry or reaction of $\mathrm{OH}$ with impurities unlikely to be important for reasons already discussed. The PLP-LIF studies used online measurement of $\mathrm{NO}_{2}$ with almost identical absorption cross sections at $365 \mathrm{~nm}$, or $\mathrm{NO}_{2}$ reference spectra with absorption cross sections that agree to within a few percent (more details in Sect. 3.1.2). In our work, we recorded the $\mathrm{NO}_{2}$ concentration using both methods (i.e. $365 \mathrm{~nm}$ and UV broadband absorption) and found no evidence for systematic bias in the $\mathrm{NO}_{2}$ concentration. Also, we showed that the $\mathrm{NO}_{2}$ cross sections are not influenced significantly by pressure. We have not identified the origin of discrepancies between these datasets but note that the plots of $k_{5}$ versus pressure in the present study are generally less scattered than in most other studies, and thus provide better constraint when deriving values for $k_{0}$ and $k_{\infty}$ (Figs. 7, 10, S4-S8).

In Fig. 9, we compare our parametrization to those of IUPAC and NASA at four different temperatures in $\mathrm{N}_{2}$. At pressures close to 1 bar and $300 \mathrm{~K}$ $\left(M \sim 2.4 \times 10^{19}\right.$ molecule $\left.\mathrm{cm}^{-3}\right)$, the IUPAC parameterization underpredicts $k_{5}$ slightly $\left(k_{5}^{\text {this work }} / k_{5}^{\text {IUPAC }} \sim 1.11\right)$

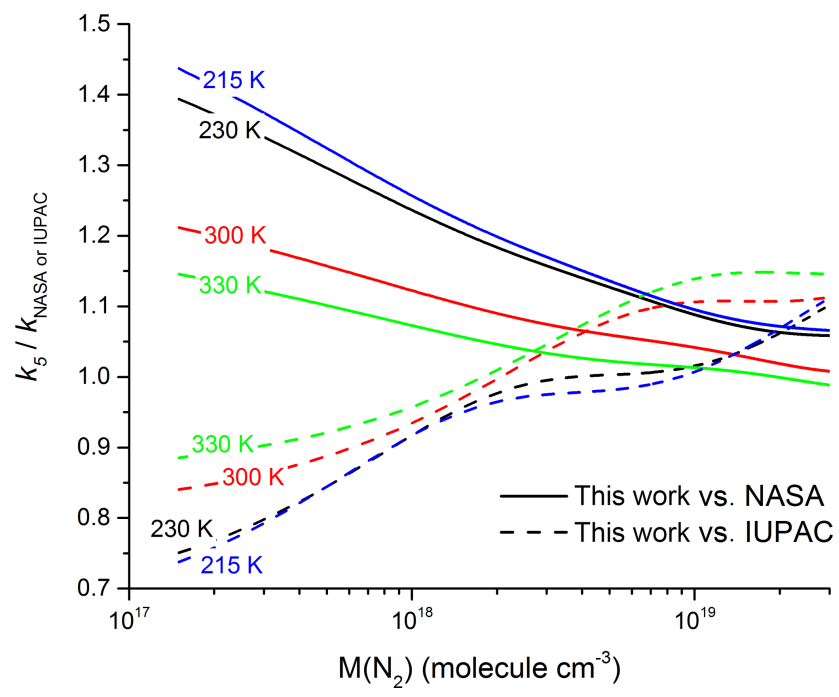

Figure 9. Ratio of our parametrized rate coefficient $k_{5}$ versus those calculated from the parameters recommended by IUPAC (dashed lines) and NASA (solid lines) for four different temperatures.

whereas the NASA parameterization is in good agreement $\left(k_{5}^{\text {this work }} / k_{5}^{\text {NASA }} \sim 1.01\right)$. At molecular densities and temperatures typical of the mid-latitude upper troposphere of $230 \mathrm{~K}$ and $M=8 \times 10^{18}$ molecule $\mathrm{cm}^{-3}(\sim 250 \mathrm{mbar})$ the situation reverses with IUPAC accurately predicting our measured values $\left(k_{5}^{\text {this } \text { work }} / k_{5}^{\mathrm{IUPAC}} \sim 1.00\right)$ and NASA overpredicting slightly $\left(k_{5}^{\text {this work }} / k_{5}^{\mathrm{NASA}} \sim 1.10\right)$. As we move up to higher altitudes the discrepancy between measurement and the NASA recommendation increases: taking a typical value of $M \sim 2 \times 10^{18}$ molecule $\mathrm{cm}^{-3}$ for the lower stratosphere $(20 \mathrm{~km}$ altitude) and a temperature of $215 \mathrm{~K}$, we calculate $\left(k_{5}^{\text {this work }} / k_{5}^{\text {IUPAC }} \sim 0.95\right)$ and $\left(k_{5}^{\text {this work }} / k_{5}^{\text {NASA }} \sim 1.20\right)$. Moving up to $35 \mathrm{~km}$ altitude $\left(M \sim 2 \times 10^{17}\right.$ molecule $\left.\mathrm{cm}^{-3}, T=230 \mathrm{~K}\right)$ deviation becomes substantial for both sets of recommendations with $\left(k_{5}^{\text {this work }} / k_{5}^{\text {IUPAC }} \sim 0.75\right)$ and $\left(k_{5}^{\text {this work }} / k_{5}^{\text {NASA }} \sim 1.35\right)$.

The great discrepancy between the IUPAC and NASA recommendations at low pressures and temperatures has its origin in the treatment of the low-pressure limit rate coefficient, $k_{0}$. In the IUPAC approach, the parametrization was constrained to the low-pressure datasets (Troe, 2012), extrapolating reported values of $k_{0}$ to a higher value assuming the data were in a pure third-order regime; however, as shown above this assumption results in an overestimation of $k_{0}$. By fixing $F_{\mathrm{c}}$ to 0.6 and constraining the fit to the highpressure measurements of Hippler et al. (2006), the NASA parametrization will tend to underestimate $k_{0}$.

In order to test this, we fitted our data to the expression used by NASA (Eq. 9) with $F_{\mathrm{c}}$ fixed at 0.6. This resulted in values of $k_{0}\left(\mathrm{~N}_{2}\right)=2.0 \times 10^{-30} \mathrm{~cm}^{6}$ molecule ${ }^{-2} \mathrm{~s}^{-1}$ and $k_{\infty}=3.6 \times 10^{-11} \mathrm{~cm}^{3}$ molecule ${ }^{-1} \mathrm{~s}^{-1}$ ( $m$ stayed unchanged with a fitted value of 3.6), which are not consistent with ei- 


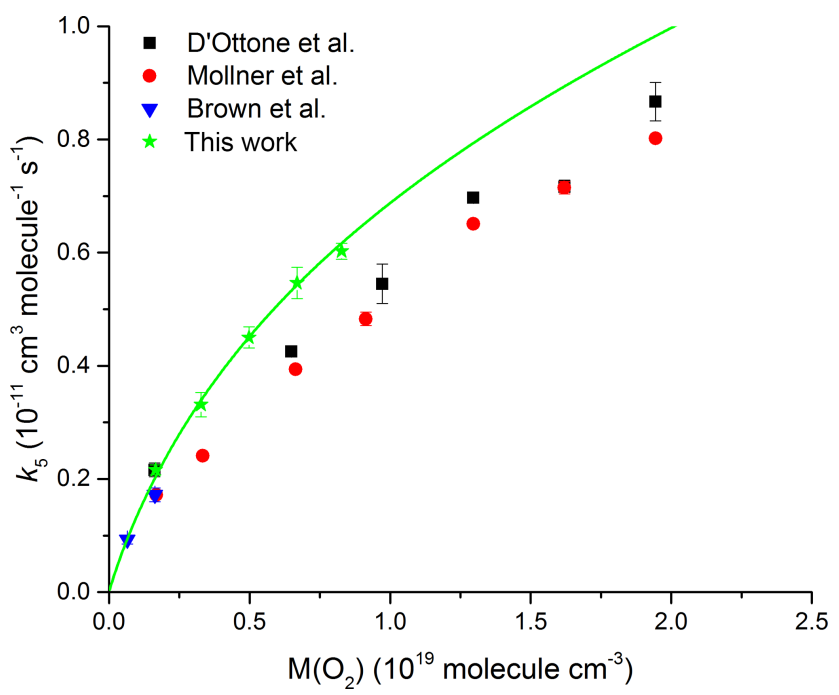

Figure 10. Rate coefficient $k_{5}$ as a function of $\mathrm{O}_{2}$ density at $T=293 \mathrm{~K}$. The green data points are from the present study; the solid line represents a fit using Eq. (5) with $k_{0}=2.0 \times 10^{-30} \mathrm{~cm}^{6}$ molecule $\mathrm{s}^{-2}$, $k_{\infty}=6.3 \times 10^{-11} \mathrm{~cm}^{3}$ molecule ${ }^{-1} \mathrm{~s}^{-1}$ (fixed), $F_{\mathrm{c}}=0.39$ (fixed), and $m=3.6$ (fixed).

ther the high- or low-pressure data.

$k_{\mathrm{NASA}}(p, T)=\frac{k_{0}\left(\frac{T}{300}\right)^{-m} M}{1+\frac{k_{0}\left(\frac{T}{300}\right)^{-m} M}{k_{\infty}\left(\frac{T}{300}\right)^{-n}}} 0.6\left[1+\left[\log \left(\frac{k_{0}\left(\frac{T}{300}\right)^{-m} M}{k_{\infty}\left(\frac{T}{300}\right)^{-n}}\right)\right]^{2}\right\}^{-1}$

\subsubsection{Measurements of $k_{5}$ in $\mathrm{O}_{2}$ bath gas and comparison with literature}

Brown et al. (1999) were the first to recognize that the thirdbody collision efficiency of $\mathrm{O}_{2}$ was lower than $\mathrm{N}_{2}$ and, as a consequence, $k_{5}$ would be lower in air than in pure $\mathrm{N}_{2}$. This was confirmed in subsequent measurements by D'Ottone et al. (2001) and Mollner et al. (2010).

We have also performed a series of measurements, displayed in Fig. 10, in pure $\mathrm{O}_{2}$ bath gas (50-250 Torr, $295 \mathrm{~K}$ ). The solid line is a fit to the data using expression (Eq. 5) whereby only $k_{0}$ was varied with $k_{\infty}, F_{\mathrm{c}}$, and $m$ fixed as $6.3 \times 10^{-11} \mathrm{~cm}^{3}$ molecule ${ }^{-1} \mathrm{~s}^{-1}, 0.39$, and 3.6 respectively. The rate coefficients obtained in pure $\mathrm{O}_{2}$ bath gas are in good agreement with the single low-pressure data point of Brown et al. (1999) but are systematically higher (by on average $10 \%$ and $30 \%$ respectively) than those reported by D'Ottone et al. (2001) and Mollner et al. (2010). As for the experiments in $\mathrm{N}_{2}$, the reason for this discrepancy is not obvious.

Our analysis results in a low-pressure limit of $k_{0}\left(\mathrm{O}_{2}\right)=2.0 \times 10^{-30} \mathrm{~cm}^{6}$ molecule $\mathrm{e}^{-2} \mathrm{~s}^{-1}$ and thus a relative collision efficiency of 0.74 for $\mathrm{O}_{2}$ compared to $\mathrm{N}_{2}$. This result is in excellent agreement with the results by Brown et al. (1999) (0.70), D'Ottone et al. (2001) (0.67), and Mollner et al. (2010) (0.67) and results in a collision efficiency in air $\left(\sim 80 \% \mathrm{~N}_{2}\right.$ and $\left.\sim 20 \% \mathrm{O}_{2}\right)$ of 0.94 relative to $\mathrm{N}_{2}$. The impact of the lower efficiency for collisional deactivation of $\mathrm{O}_{2}$ compared to $\mathrm{N}_{2}$ will be largest close to the low-pressure limit and tends to zero as we approach the high-pressure limit. At low pressures, we calculate a rate coefficient that will be lower by $5 \%$ in air compared to $\mathrm{N}_{2}$, while at $1 \mathrm{~atm}$, the reduction in $k_{5}$ will be $\sim 3 \%$. To date, the NASA evaluation panel has incorporated this effect into its recommendations, whereas the IUPAC panel has not. We have not investigated the temperature dependence of the low-pressure rate coefficient $(m)$ in $\mathrm{O}_{2}$ but note that previous studies of $k_{5}$ close to the low-pressure limit indicate the same values of $m$ for $\mathrm{He}, \mathrm{N}_{2}$, and Ar even though the third-body efficiencies of these three bath gases are very different (Anderson et al., 1974). There is no reason to expect that this would be different for $\mathrm{O}_{2}$ and therefore do not consider the assumption of the same value of $m$ for $\mathrm{N}_{2}$ and $\mathrm{O}_{2}$ to be a source of uncertainty in deriving rate coefficients for atmospheric conditions (i.e. a mixture of $\mathrm{N}_{2}$ and $\mathrm{O}_{2}$ ). We emphasize that, for use in atmospheric models, both the lower third body of efficiency of air compared to $\mathrm{N}_{2}$ and the branching ratio to $\mathrm{HNO}_{3}$ or HOONO formation need to be considered.

\section{Conclusion}

We report a new set of measurements of the rate coefficient $\left(k_{5}\right)$ for the reaction of $\mathrm{OH}$ with $\mathrm{NO}_{2}$ between 217 and $333 \mathrm{~K}$ and over a wide range a pressures in the fall-off regime in $\mathrm{N}_{2}$ and $\mathrm{O}_{2}$ bath gases. In order to measure $\mathrm{NO}_{2}$ concentrations as accurately as possible we used three different optical absorption set-ups at different wavelengths/wavelength ranges as well as in situ, laser-induced-fluorescence detection of $\mathrm{NO}_{2}$. The highly accurate and precise dataset obtained, combined with a theoretical value for the fall-off factor, enabled a more accurate assessment of the limiting lowpressure $\left(k_{0}\right)$ rate coefficient than previous studies, including low-pressure flow-tube measurements. The rate coefficients we derive in the fall-off range are slightly larger than some previous studies using similar methods and the values for $k_{\infty}$ are consistent with previous reports of this parameter based on experiments in high pressures of $\mathrm{He}$ and vibrational deactivation of $\mathrm{OH}$ in collision with $\mathrm{NO}_{2}$.

We derive a parameterization of the overall rate coefficient and show that present divergent evaluations of $k_{5}$ result in significant differences, both underestimating and overestimating the rate coefficient in different parts of the atmosphere. Further study of the temperature and pressure dependence of the branching ratios on $\mathrm{HNO}_{3}$ and $\mathrm{HOONO}$ formation as well as of the atmospheric fate of HOONO are required to fully understand and model the atmospheric impact of the title reaction. 
Data availability. The rate coefficients measured during this experimental study are listed in Table 1.

Supplement. The supplement related to this article is available online at: https://doi.org/10.5194/acp-19-10643-2019-supplement.

Author contributions. The experiments were carried out by DA, AJCB, and MB. The data analysis and preparation of the paper were performed by DA, with assistance from JNC, who designed the study.

Competing interests. The authors declare that they have no conflict of interest.

Financial support. The article processing charges for this openaccess publication were covered by the Max Planck Society.

Review statement. This paper was edited by Rainer Volkamer and reviewed by Anthony Hynes and two anonymous referees.

\section{References}

Anastasi, C. and Smith, I. W. M.: Rate measurements of reactions of $\mathrm{OH}$ by resonance absorption. Part 5. - Rate constants for $\mathrm{OH}+\mathrm{NO}_{2}(+M) \rightarrow \mathrm{HNO}_{3}(+M)$ over a wide range of temperature and pressure, J. Chem. Soc., Faraday T. 2, 72, 1459-1468, 1976.

Anderson, J. G. and Kaufman, F.: Kinetics of reaction $\mathrm{OH}+\mathrm{NO}_{2}+M \rightarrow \mathrm{HNO}_{3}+M$, Chem. Phys. Lett., 16, 375-379, 1972.

Anderson, J. G., Margitan, J. J., and Kaufman, F.: Gas-phase recombination of $\mathrm{OH}$ with $\mathrm{NO}$ and $\mathrm{NO}_{2}$, J. Chem. Phys., 60, 33103317, 1974.

Anderson, L. G.: Absolute rate constants for the reaction of $\mathrm{OH}$ with $\mathrm{NO}_{2}$ in $\mathrm{N}_{2}$ and $\mathrm{He}$ from 225 to $389 \mathrm{~K}$, J. Phys. Chem., 84, 2152-2155, 1980.

Atkinson, R., Baulch, D. L., Cox, R. A., Crowley, J. N., Hampson, R. F., Hynes, R. G., Jenkin, M. E., Rossi, M. J., and Troe, J.: Evaluated kinetic and photochemical data for atmospheric chemistry: Volume $\mathrm{I}-$ gas phase reactions of $\mathrm{O}_{\mathrm{x}}, \mathrm{HO}_{\mathrm{X}}$, $\mathrm{NO}_{\mathrm{x}}$ and $\mathrm{SO}_{\mathrm{x}}$ species, Atmos. Chem. Phys., 4, 1461-1738, https://doi.org/10.5194/acp-4-1461-2004, 2004.

Atkinson, R., Baulch, D. L., Cox, R. A., Crowley, J. N., Hampson, R. F., Hynes, R. G., Jenkin, M. E., Rossi, M. J., Troe, J., and IUPAC Subcommittee: Evaluated kinetic and photochemical data for atmospheric chemistry: Volume II - gas phase reactions of organic species, Atmos. Chem. Phys., 6, 3625-4055, https://doi.org/10.5194/acp-6-3625-2006, 2006.

$\mathrm{Au}$, J. W. and Brion, C. E.: Absolute oscillator strengths for the valence-shell photoabsorption $(2-200 \mathrm{eV})$ and the molecular and dissociative photoionization $(11-80 \mathrm{eV})$ of nitrogen dioxide, Chem. Phys., 218, 109-126, 1997.
Brown, R. L.: Tubular flow reactors with first-order kinetics, J. Res. Nat. Bur. Sta., 83, 1-8, 1978.

Brown, S. S., Talukdar, R. K., and Ravishankara, A. R.: Rate constants for the reaction $\mathrm{OH}+\mathrm{NO}_{2}+M \rightarrow \mathrm{HNO}_{3}+M$ under atmospheric conditions, Chem. Phys. Lett., 299, 277-284, 1999.

Burkholder, J. B., Sander, S. P., Abbatt, J., Barker, J. R., Huie, R. E., Kolb, C. E., Kurylo, M. J., Orkin, V. L., Wilmouth, D. M., and Wine, P. H.: Chemical Kinetics and Photochemical Data for Use in Atmospheric Studies, Evaluation No. 18, JPL Publication 15-10, Jet Propulsion Laboratory, Pasadena, available at: http://jpldataeval.jpl.nasa.gov (last access: August 2019), 2015.

Burrows, J. P., Wallington, T. J., and Wayne, R. P.: Kinetics of the gas-phase reactions of $\mathrm{OH}$ with $\mathrm{NO}_{2}$ and with $\mathrm{NO}$, J. Chemical Soc.-Faraday T. II, 79, 111-122, 1983.

Cobos, C. J. and Troe, J.: Prediction of reduced falloff curves for recombination reactions at low temperatures, Z. Phys. Chem., 217, 1031-1044, 2003.

Donahue, N. M., Dubey, M. K., Mohrschladt, R., Demerjian, K. L., and Anderson, J. G.: High-pressure flow study of the reactions $\mathrm{OH}+\mathrm{NO}_{x} \rightarrow \mathrm{HONO}_{x}$ : Errors in the falloff region, J. Geophys. Res.-Atmos., 102, 6159-6168, 1997.

D’Ottone, L., Campuzano-Jost, P., Bauer, D., and Hynes, A. J.: A pulsed laser photolysis-pulsed laser induced fluorescence study of the kinetics of the gas-phase reaction of $\mathrm{OH}$ with $\mathrm{NO}_{2}$, J. Phys. Chem. A, 105, 10538-10543, 2001.

D’Ottone, L., Bauer, D., Campuzano-Jost, P., Fardy, M., and Hynes, A. J.: Kinetic and mechanistic studies of the recombination of $\mathrm{OH}$ with $\mathrm{NO}_{2}$ : Vibrational deactivation, isotopic scrambling and product isomer branching ratios, Faraday Discuss., 130, 111-123, 2005.

Dransfield, T. J., Perkins, K. K., Donahue, N. M., Anderson, J. G., Sprengnether, M. M., and Demerjian, K. L.: Temperature and pressure dependent kinetics of the gas-phase reaction of the hydroxyl radical with nitrogen dioxide, Geophys. Res. Lett., 26, 687-690, 1999.

Dulitz, K., Amedro, D., Dillon, T. J., Pozzer, A., and Crowley, J. N.: Temperature-(208-318 K) and pressure-(18-696 Torr) dependent rate coefficients for the reaction between $\mathrm{OH}$ and $\mathrm{HNO}_{3}$, Atmos. Chem. Phys., 18, 2381-2394, https://doi.org/10.5194/acp18-2381-2018, 2018.

Golden, D. M., Barker, J. R., and Lohr, L. L.: Master equation models for the pressure- and temperature-dependant reactions $\mathrm{HO}+\mathrm{NO}_{2} \rightarrow \mathrm{HONO}_{2}$ and $\mathrm{HO}+\mathrm{NO}_{2} \rightarrow \mathrm{HOONO}, \mathrm{J}$. Phys. Chem. A, 107, 11057-11071, 2003.

Hippler, H., Nasterlack, S., and Striebel, F.: Reaction of $\mathrm{OH}+\mathrm{NO}_{2}+M$ : Kinetic evidence of isomer formation, Phys. Chem. Chem. Phys., 4, 2959-2964, 2002.

Hippler, H., Krasteva, N., Nasterlack, S., and Striebel, F.: Reaction of $\mathrm{OH}+\mathrm{NO}_{2}$ : High pressure experiments and falloff analysis, $\mathrm{J}$. Phys. Chem. A, 110, 6781-6788, 2006.

Howard, C. J. and Evenson, K. M.: Laser magnetic-resonance study of gas-phase reactions of $\mathrm{OH}$ with $\mathrm{CO}, \mathrm{NO}$, and $\mathrm{NO}_{2}$, J. Chem. Phys., 61, 1943-1952, 1974.

Howard, C. J.: Kinetic measurements using flow tubes, J. Phys. Chem., 83, 3-9, 1979.

IUPAC: Task Group on Atmospheric Chemical Kinetic Data Evaluation, edited by: Ammann, M., Cox, R. A., Crowley, J. N., Herrmann, H., Jenkin, M. E., McNeill, V. F., Mellouki, A., Rossi, 
M. J., Troe, J., and Wallington, T. J., available at: http://iupac. pole-ether.fr/index.html, last access: March 2019.

Keil, D. G., Donnelly, V. M., and Kaufman, F.: Fluorescence lifetime studies of $\mathrm{NO}_{2}$. IV. Temperature dependence of fluorescence spectra and of collisional quenching of fluorescence, J. Chem. Phys., 73, 1514-1520, 1980.

Keyser, L. F.: High-pressure flow kinetics - A study of the $\mathrm{OH}+\mathrm{HCl}$ reaction from 2 to 100 Torr, J. Phys. Chem., 88, 4750$4758,1984$.

Lelieveld, J., Dentener, F. J., Peters, W., and Krol, M. C.: On the role of hydroxyl radicals in the self-cleansing capacity of the troposphere, Atmos. Chem. Phys., 4, 2337-2344, https://doi.org/10.5194/acp-4-2337-2004, 2004.

Lelieveld, J., Gromov, S., Pozzer, A., and Taraborrelli, D.: Global tropospheric hydroxyl distribution, budget and reactivity, Atmos. Chem. Phys., 16, 12477-12493, https://doi.org/10.5194/acp-1612477-2016, 2016.

Merienne, M. F., Jenouvrier, A., and Coquart, B.: The $\mathrm{NO}_{2}$ absorption-spectrum. 1. Absorption cross-sections at ambienttemperature in the $300-500 \mathrm{~nm}$ region, J. Atmos. Chem., 20, 281-297, 1995.

Mollner, A. K., Valluvadasan, S., Feng, L., Sprague, M. K., Okumura, M., Milligan, D. B., Bloss, W. J., Sander, S. P., Martien, P. T., Harley, R. A., McCoy, A. B., and Carter, W. P. L.: Rate of gas phase association of hydroxyl radical and nitrogen dioxide, Science, 330, 646-649, 2010.

Newsome, B. and Evans, M.: Impact of uncertainties in inorganic chemical rate constants on tropospheric composition and ozone radiative forcing, Atmos. Chem. Phys., 17, 14333-14352, https://doi.org/10.5194/acp-17-14333-2017, 2017.

Nizkorodov, S. A., Sander, S. P., and Brown, L. R.: Temperature and pressure dependence of high-resolution air-broadened absorption cross sections of $\mathrm{NO}_{2}(415-525 \mathrm{~nm})$, J. Phys. Chem. A, 108, 4864-4872, 2004.

Orphal, J.: A critical review of the absorption cross-sections of $\mathrm{O}_{3}$ and $\mathrm{NO}_{2}$ in the ultraviolet and visible, J. Photochem. Photobiol. A, 157, 185-209, 2003.
Schurath, U., Lippmann, H. H., and Jesser, B.: Temperature dependence of the chemiluminescent reaction (1), $\mathrm{NO}+\mathrm{O}_{3} \rightarrow \mathrm{NO}_{2}\left({ }^{2} A_{1} ;{ }^{2} B_{1}, 2\right)+\mathrm{O}_{2}$, and quenching of the excited product, Berichte der Bunsengesellschaft für physikalische Chemie, 85, 807-813, 1981.

Smith, I. W. and Williams, M. D.: Vibrational-relaxation of $\mathrm{OH}(v=$ 1) and $\mathrm{OD}(v=1) \mathrm{By} \mathrm{HNO}_{3}, \mathrm{DNO}_{3}, \mathrm{H}_{2} \mathrm{O}, \mathrm{NO}$ and $\mathrm{NO}_{2}, \mathrm{~J}$. Chem. Soc. Faraday Trans. 2, 81, 1849-1860, 1985.

Troe, J.: Theory of thermal unimolecular reactions in the fall-off range 1. Strong collision rate constants, Berichte Der BunsenGesellschaft-Physical Chemistry Chemical Physics, 87, 161$169,1983$.

Troe, J.: Refined representation of falloff curves for the reaction $\mathrm{HO}+\mathrm{NO}_{2}+\mathrm{N}_{2} \rightarrow\left(\mathrm{HONO}_{2}, \mathrm{HOONO}\right)+\mathrm{N}_{2}$, J. Phys. Chem. A, 116, 6387-6393, 2012.

Vandaele, A. C., Hermans, C., Simon, P. C., Carleer, M., Colin, R., Fally, S., Merienne, M. F., Jenouvrier, A., and Coquart, B.: Measurements of the $\mathrm{NO}_{2}$ absorption cross-section from $42000 \mathrm{~cm}^{-1}$ to $10000 \mathrm{~cm}^{-1}(238-1000 \mathrm{~nm})$ at $220 \mathrm{~K}$ and 294 K, J. Quant. Spectrosc. Ra., 59, 171-184, 1998.

Vandaele, A. C., Hermans, C., Fally, S., Carleer, M., Colin, R., Merienne, M. F., Jenouvrier, A., and Coquart, B.: Highresolution Fourier transform measurement of the $\mathrm{NO}_{2}$ visible and near-infrared absorption cross sections: Temperature and pressure effects, J. Geophys. Res.-Atmos., 107, 4348, https://doi.org/10.1029/2001JD000971, 2002.

Wine, P. H., Kreutter, N. M., and Ravishankara, A. R.: Flash photolysis-resonance fluorescence kinetics study of the reaction $\mathrm{OH}+\mathrm{NO}_{2}+M \rightarrow \mathrm{HNO}_{3}+M$, J. Phys. Chem., 83, 3191-3195, 1979.

Wollenhaupt, M., Carl, S. A., Horowitz, A., and Crowley, J. N.: Rate coefficients for reaction of $\mathrm{OH}$ with acetone between 202 and 395 K, J. Phys. Chem., 104, 2695-2705, 2000.

Yoshino, K., Esmond, J. R., and Parkinson, W. H.: High-resolution absorption cross section measurements of $\mathrm{NO}_{2}$ in the UV and visible region, Chem. Phys., 221, 169-174, 1997. 